\title{
HUNGARIAN PSYCHOLOGY IN CONTEXT. RECLAIMING THE PAST
}

\author{
ÁGNES SZOKOLSZKY \\ Department of Psychology, Szeged University \\ E-mail: szokolszky@gmail.com
}

\begin{abstract}
The "contextualizing" and "internationalizing" of the history of psychology is an ongoing project, however, Central Europe, as a coherent perspective, and the history of Hungarian psychology specifically, is acutely missing in current surveys of international psychology, and more broadly, in "western consciousness". This paper is an attempt at presenting a comprehensive, socially and politically contextualized framework of the history of Hungarian psychology, from its beginnings until the fall of communism. The paper situates the history of psychology in the history of Hungary since without this broader background Hungarian psychology cannot be treated as a contextualized phenomenon. Reconstructing the history of Hungarian psychology is, at the same time, reclaiming the past, since continuity with, and remembrance of the past was once forcefully obstructed by the communist regime, and the effects proved to be long lasting. Hungarian psychology was, in part, a genuine "extension" of psychology as it developed in Germany and more broadly in Europe, but also a unique and remarkable phenomenon greatly shaped by specific socio-political context. Scholarship on the history of Hungarian psychology is growing fast, but the richness of this history has yet to be more fully explored and appreciated, inside and outside of Hungary.
\end{abstract}

Keywords: history of Hungarian psychology, new history of psychology, contextualizing psychology, Budapest School of Psychoanalysis, Hungarian Phenomenon

Acknowledgements: I am grateful to Alice Freifeld, who invited me to give a talk on the history of Hungarian Psychology at the University of Florida in January 2014 - this talk forms the core of this paper. I am thankful to Don Dewsbury for encouragement and feedback, and to Catherine Read for her comments and editorial advice. I greatly thank Csaba Pléh for comments and advice.

The "new history of psychology" (Furumoto, 1989, Harris, 2009, Pickren and Rutherford, 2010) acknowledges that psychology is a socio-cultural phenomenon with intricate roots in the particulars of time and space. This kind of history writing shows an increased appreciation of the sociological, cultural and political factors that are inexorably present wherever psychology as a field develops. In this framework of "contextualizing" and "internationalizing" the history of psychology specific national histories are important. Work has been published, 
for example, in the context of India (Paranjpe, 2006), Argentina (Taiana, 2006), China (Blowers, 2006, Gao, 2012), Turkey (Gulerce, 2006), the Soviet Union (Kozulin, 1984, Valenstein, 2011), and the Ukraine (Holowinsky, 2008). Decentering from the Western perspective is a strong motivation behind this work, which has expanded our understanding of what psychology is. The "European perspective", however, still has aspects that have hardly been elaborated as coherent histories. So is the angle of Central Europe - a region at the very heart of the birth of psychology. Central Europe, as a coherent historical - cultural - geopolitical perspective, and the history of Hungarian psychology specifically, is acutely missing in surveys of international psychology, and more broadly, in "western consciousness".

Central Europe exists in the shared history and cultural heritage of Germany and the Austro-Hungarian Monarchy. Following World War II, this region became politically divided. East-Germany, Poland, Czechoslovakia and Hungary - countries historically tied to the West - became part of the Eastern Bloc under Soviet rule. The dissident Czech writer, Milan Kundera calls the disappearance of the whole region from the West "the tragedy of Central Europe" (Kundera, 1984). Disappearance from the West brought along the disappearance of big chunks of collective memory. Communist regimes, as "engineers of memory and forgetfulness" (Schwarcz, 1999, 50) were so efficient in determining what and how could and could not be remembered, that collective amnesia was in effect up until recently, regarding many aspects of the past.

However, Central Europe was beset by calamities long before the communist rule. The multinational Austro-Hungarian Monarchy was the constitutional union of the Austrian Empire and the Hungarian Kingdom. Austria-Hungary was geographically the second largest country in Europe after the Russian Empire and the third most populous country after Russia and Germany. As one of the Central Powers it ended World War I defeated and collapsed. Along with the establishment of the successor states of Austria, Hungary, Czechoslovakia, Poland, and Yugoslavia, deep seated animosity among the new nation states was introduced in the region. In the Treaty of Trianon Hungary lost $70 \%$ of its historical territory and half of its population. Revisionism remained a major factor of political life between the two world wars and was the main reason for the participation of Hungary on the side of Germany in World War II.

During its existence Austria-Hungary had cultural coherence and became a significant place of intellectual life, with Vienna, Budapest and Prague leading the way. In a region where emerging national and group identities were repeatedly threatened while being formed, cultural and intellectual life grew especially intense and important. In spite, or rather, because of its complicated history, Central Europe became a creative space for human talent. Psychology as a new science was largely formed in the fertile intellectual soil of Germany, but it is more than 
symbolic that the Austrian Sigmund Freud was born to Jewish Galician parents in Moravia (later Czechoslovakia), and that Budapest became the first cradle of psychoanalysis outside of Vienna.

Until the end of World War II Hungarian psychology was, in a way, a genuine "extension" of psychology as it developed in Germany, Austria, and more broadly in Europe, but also a unique and remarkable phenomenon rooted in local conditions greatly shaped by specific social and political history. The four decades of communist rule after World War II presented a sharply discontinuous period during which Hungarian psychology followed the Soviet model. Throughout this history, psychologists were not just victims of conditions but also actors who participated in forming and maintaining those conditions.

Even though reconstructing the past is well under way by contemporary Hungarian historians of psychology, many details, as well as the comprehensive, contextualized history of Hungarian psychology still remain to be explored and published nationally and internationally. ${ }^{2}$ Social-political background and historical events are seldom discussed explicitly in the context of history of psychology. In the present case, however, situating the history of psychology in history proper is especially relevant, since without this broader background Hungarian psychology cannot be considered as a contextualized phenomenon. I treat Hungarian psychology as a phenomenon situated in history, embedded in socio-cultural context, and pursued by professionals who had to face sometimes extremely difficult situations imposed upon them by history. My aim is to weave together existing knowledge of the past in a coherent history that highlights how psychology as an academic and professional enterprise was both boosted and constrained by sociocultural and geopolitical contexts in this specific region of Europe.

Political history marked distinct eras not only in national history, but also in the history of Hungarian psychology - therefore the presentation will follow these historical division points.

\section{Society and intellectual life before World War I}

Within the dual monarchy of the Austro-Hungarian Empire (1867-1914)

Within the boundaries of the dual monarchy (1867-1918) Hungary witnessed a strong economic and social development. Before World War I Budapest was the fastest growing city in Europe, attracting an inflow of newcomers from the countryside. Splendid buildings were raised, and cultural and intellectual life flourished, including philosophy, sociology, music, the fine arts, and literature. Coffee houses were centers of intellectual life, comparable to those in Vienna, and both cities had a vivid atmosphere, along with social tensions (Lukacs, 1990). Society was in a flux: industrialists established state-of-the-art factories, at the 
same time urban poverty grew. While landlords in the countryside owned huge estates, nearly two million poor peasants and unskilled workers immigrated to the United States from the historical territory of Hungary (Várdy, 2012). The emerging burocratic systems of the modernized state: medical care, education, and the military, called for change and new professional practices. Intellectuals (social scientists, writers and artists) were keenly aware of these processes and conducted heated discussions about the ways to reform Hungary. Like other growing cities in Europe, Budapest shared the ambiance of modernity: the feeling that "all that is solid melts in the air" (Berman, 1982, title cited).

Hungarian national identity was complex: it incorporated the sense of being the defender of Christian Europe for the 150 years of Turkish occupation, the tradition of rebelliousness in fighting the Habsburgs, the sense of "standing alone" with an isolated language, and a long tradition of the assimilation of various ethnicities. Paul Lendvai, for example, pointed out as paradigmatic that Hungary's greatest poet-patriot, Sándor Petőfi was of Slovak descent, and Franz Liszt, although spoke only a few words of Hungarian, had a deep sense of Hungarian identity (Lendvai, 2014). ${ }^{3}$

A significant Jewish population lived in Hungary (mostly in Budapest), who enjoyed a period of unprecedented upward mobility and prosperity. In 1867 an emancipation bill granted equal civil rights to Hungarian Jews. The modernization of the economy needed the Jewish entrepreneurial spirit and soon their contribution to economic growth, as well as to art, science, and culture rose to unparalleled levels. Assimilation, secularization and conversion to Christianity became prominent trends among Hungarian Jews. Wealthy Jewish industrialists received titles of nobility from the Emperor-King Francis Joseph I. In this "golden age" of the Hungarian Jewry (Patai, 1996) Budapest became a significant center for Jewish culture. While anti-Semitism was an ever-present current, the Jewish population was assimilated and secularized beyond the European average (Nye, 2011). Talented Jewish youth flocked to the universities and into the free professions such as journalism and medicine (as Jews were still being banned from state office employment, showing the limitation of "equal rights"). This was all the more so as the Hungarian upper and middle class, with traditional feudal mentality, favored jobs in the state burocracy over market-related professions such as law, engineering and medical practice. Jewish contribution to psychology was substantial, and, in fact, neither modern Hungarian history and culture, nor the history of Hungarian psychology can be understood without understanding the significant role played by Jewish-Hungarians.

Hungarian universities were much weaker and lesser in number than their German and Austrian counterparts, but they also significantly developed by the turn of the century. The major university of Hungary was in Budapest. Its predecessor was founded in 1635 by Cardinal Péter Pázmány as a Catholic school. In the $18^{\text {th }}$ 
century it moved to Pest and became Pázmány University, with German as the official language of operation. After the 1848 Hungarian Revolution and War for Independence from the Austrian Empire was crushed, the Habsburgs-appointed government modernized the university in the spirit of the Humboldt reforms. As a result the university greatly expanded both in the natural and the social sciences. A Technical University was also founded in 1872 in Budapest, the first of its kind in Europe. A major university was established the same year in the city of Kolozsvár (today: Cluj, in Romania), the largest Hungarian center in Transylvania, also as continuation of a Jesuit academy dating back to 1581. A fourth university was established in 1912 in Pozsony (today: Bratislava, the capital of Slovakia), followed by two modern universities in the same year in Pécs and in Debrecen (two Hungarian cities where higher education had strong roots in medieval history). The faculty in all of these universities consisted of qualified scientists who were strongly integrated in the German speaking academic world. They spent time typically in Austrian and German universities or research institutions and published in German, in addition to Hungarian.

By the turn of the century Hungary also had a strong secondary level education. In the 1880s a reform was initiated at this level of the school system by Mór Kármán, who also instituted teacher training. The reform modernized the curriculum and the educational practice in the framework of Johann Friedrich Herbart's theory, who founded pedagogy as an academic principle in Germany and worked out a systematic method of education applicable for all subjects. In the secondary schools - called "gymnasiums" - teachers were often themselves publishing scientists, and the curriculum combined the Greek and Roman classics with knowledge of the sciences. Strong emphasis was placed on character development and moral education, as well as on national history and literature, and the unity of national and European culture, in accordance with the values of national liberalism (Pukánszky and Németh, 1996).

Hungarian psychology emanated in this ambiguous state of emerging Central European modernity, and showed overall development until the end of the 1930's, in spite of political upheavals.

\section{The beginnings of psychology}

Phrenology, characterology and other trends pointing towards psychology appeared in Hungary parallel with other regions in Europe. Discussions of the new science of psychology emerged as soon as the idea started to spread in the second half of the $19^{\text {th }}$ century. Several authors in philosophy, pedagogy and linguistics started to work on making the new science known for the wider public, and they made original contributions to ongoing topics and debates in psychology. 
Well before the turn of the century psychology was introduced in the framework of university lectures and even in the curriculum of the gymnasiums. Professors and teachers of philosophy, pedagogy and medicine incorporated the new field into their subject matter (Deák, 2000, Pléh, 1997, 2009, Pléh, Bodor and Lányi, 1998). These developments were certainly facilitated by the fact that Hungary was an integral part of the German-speaking culture of Central Europe.

As elsewhere, psychology as a praxis emerged as a response to various social demands. Due to urbanization mental health problems greatly increased and in 1868 the first state mental hospital - The National Institute of Psychiatry and Neurology - was opened in Budapest, formed in the fashion of similar state-ofthe art European institutions (for a detailed discussion see Lafferton, 2003, 2004, Kovai, 2015). This marked a boost for psychiatry and raised interest in problems of mental functioning and in the new science of psychology. Well educated professionals were ready to employ the new knowledge in innovative ways. An early representative of this trend was, for example, Károly Lechner (1850-1922), born to a Hungarian family of German roots, who conducted his medical studies in Vienna and Budapest and spent two years working at the most advanced psychiatry and psychology centers in Europe, including Wilhelm Wundt's Laboratory in Leipzig and Jean-Martin Charcot's Clinic in Paris. After returning to Hungary he organized a later internationally famous Clinic of Psychiatry and Psychology at the University at Kolozsvár, developed a theory of mental functioning and pursued empirical psycho-physiological research using reaction time measures (Fodor and Kós, 1995). ${ }^{4}$

Another major social demand was related to the changing position of children in a changing society. Social tasks in this regard were numerous: the problem of abandoned, "morally depraved" and criminally involved children had to be addressed. Children also had to be filtered for the purpose of schooling, what brought up the problem of the "feeble minded", however, it became also desirable to identify talented children, and provide families with advice on how to raise children. Psychology offered scientific means to deal with these problems (Kovai, 2015).

Reform-minded educators and teachers started writing and lecturing on the scientific study of the child already in the 1890s (Deák, 2000). László Nagy (1857-1931), lecturer at the Hungarian Teacher Training College became the main leader and organizer of the Hungarian child study movement, which soon became highly successful, even by international standards. On Nagy's initiative, the National Congress on Education in 1889 put on its agenda the discussion of scientific child study. Representatives of Herbartianist pedagogy criticized the positivist "psychotechnik" promoted by the field of child study, but the idea that children's welfare and bodily, mental, moral and social development should be based on empirical data and should be addressed as an integrated issue, as well as 
the idea of scientific measurement gained popularity. Published reports written by teachers on their observations and measurements of school children increased following the Congress (Deák, 2000). László Nagy established the Hungarian Child Study Association in 1906 and launched the journal A Gyermek ("The Child"). The agenda included the preparation of school reforms, the establishment of a state institution for "nervous children", cooperation with parents, workshops for teachers, and the promotion of legal reforms for children involved in crime. Child study laboratories were established in several high schools, and in the Hungarian Teacher Training College, on Nagy's incentive. Even a Child Study Museum was opened in order to disseminate research results. Members of the Hungarian movement were active in international gatherings, such as the International Conference of Child Psychologists in Jena and the International Congress of Psychologists in Rome (Deák, 2000, Pukánszky and Németh, 1996). William Stern visited Budapest in 1914, and subsequently he maintained a personal relationship with László Nagy (Deák, 2000).

With all the prevailing trends in German psychology appearing in Hungary, the establishment of experimental psychology was to be expected. This field found its prepared mind in the person of Pál Ranschburg (1870-1945), who played a vital role in Hungarian psychology throughout his career. Ranschburg came from an orthodox rabbinate Jewish family from western Hungary. He received his M.D. at the University of Budapest in the 1890s, and went for a study tour in Leipzig, visiting Wilhelm Wundt's Laboratory, then to France and Switzerland. After returning to Hungary he established the first Psycho-Physiological Laboratory at the Nervous Disease Department of the Medical Faculty in Budapest, in 1899 (Torda, 1995). Because of the hostility of the Medical Faculty against the natural science methods to study the mind, combined with lingering anti-Semitism, the lab eventually had to move under the roof of the Training College for Teachers of the Handicapped. Ranschburg became interested in child psychiatry and conducted, among many other topics, comparative studies of normally and abnormally developing children. Pál Ranschburg was a founding member of the Hungarian Child Study Association, where he became head of the Experimental Psychology Division (Deák, 2000). He produced a network of follower's, which resulted in close interconnections among experimental psychology, special education, and the child study movement, which was a special feature of Hungarian psychology (Gordosné, 2013, Pléh, 1997). Ranschburg mainly pursued research on memory, related to neuro- and psychopathology. He became internationally renowned when he published a paper in 1902 on a new phenomenon that he observed and named "homogeneous inhibition", describing the difficulty in recall presented by similar or homogeneous elements in a learning list. Homogeneous inhibition, or the "Ranschburg effect" is still a relevant topic in memory research (e.g. Kahana and Jacobs, 2000). Besides his scientific 
work Ranschburg also served as the first president of the Hungarian Psychological Association and was leading member of other professional organizations (Pléh, 1997, Lányi, 2013a)

Experimental psychology was also pioneered by Géza Révész at the Pázmány University of Budapest. ${ }^{6}$ However, it was psychoanalysis that quickly became dominant in Hungarian psychology. The leader and initiator of Hungarian psychoanalysis was Sándor Ferenczi (1873-1933), who came from an assimilated Jewish Hungarian family. His father changed the family name to the Hungariansounding 'Ferenczi' out of patriotism. After receiving his M.D. from the University of Vienna in 1894, Ferenczi returned to work in Hungary as a neurologist. When he first met Sigmund Freud in 1908, he was already 35 years old, and author of a great number of medical publications. Upon meeting they immediately formed a close relationship that Freud later described as "community of life, thought, and interests" (cited by Haynal, 1996, 27). In the following years Ferenczi became a member of Freud's inner circle and they were in intense, often intimate and mutually formative correspondence for 25 years. He often visited Freud in Vienna and accompanied him on many travels, including the journey to Clark University in the United States in 1909. In 1910 Ferenczi initiated the foundation of the International Psychoanalytic Association, and soon founded the Hungarian Psychoanalytic Society in 1913. During the war he set up an informal psychoanalytic clinic where "war neurosis" cases, and also people who could not afford paying were treated. He organized the first International Congress of Psychoanalysis in 1918 in Budapest. In the meantime he established a circle of followers, later known as Budapest School of Psychoanalysis (Erős, 2012, Haynal, 1996, Moreau-Ricaud, 1996).

Ferenczi was strongly involved in the coffee-house culture of the Budapest intelligentsia, and, specifically, in the modernist avant-garde circles in Budapest, represented among others by the prestigious literary magazine Nyugat ("The West") and the social science periodical Huszadik Század ("Twentieth Century"). He maintained friendship with leading literary figures, such as Ignotus (editor of Nyugat) and writer Sándor (Alexander) Márai. Under his influence several famous poets underwent therapeutic analysis (Moreau-Ricaud, 1996, 2012). Modernist literary forums disseminated psychoanalysis, which became popular in lay upper circles. Ferenczi rightly wrote to Freud in 1912 that "analytic fever hit Budapest" (cited by Moreau-Ricaud, 1996, 50). Thus, Ferenczi became a catalyst not only for the international psychoanalytic movement, but also for the crossfertilization of psychoanalysis and wider Hungarian culture (Mészáros, 2012). For years Freud considered Ferenczi as his main successor in the psychoanalytic movement. In a letter to Karl Abraham in August 1918, Freud claimed that he believed Budapest was well on its way to becoming the center of the psychoanalytic movement (Mészáros, 2012). 
Ferenczi was also involved in radical socialist circles, as a devotee of social change. At the turn of the century intellectuals hotly debated ways of modernization and fighting backwardness. Young sociologists and politicians led by Oszkár Jászi believed in positivist science and were in favor of radical social reforms, including land ownership. In the group called "Vasárnapi Kör" ("Sunday Circle") anti-positivist, later Marxist philosophers, social scientists and aestheticians (including philosopher György Lukács, sociologist Karl Mannheim, and art historian Arnold Hauser) discussed necessary social change along with problems of the social history of art and the sociology of knowledge. In the "Galilei Kör" ("Galileo Circle”) led by Károly (Karl) Polányi radical atheist - antimilitarist university students gathered. Sándor Ferenczi was also a member of the Galileo Circle where he held lectures on psychoanalysis. Around the aforementioned journal Nyugat ("The West") a wide circle of significant writers clustered, attracted to Symbolism, Jugendstil, and psychoanalysis. Zoltán Kodály and Béla Bartók championed new avenues in composing music, the group of painters called "Nyolcak" ("The Eight") and other avant-garde activists worked on renewing fine arts. Issues in art, science, and social commitment were intertwined, and trends and persons were in complex interrelationships (for profound discussions of this era from the point of art and culture see Pók, 1994, Szegedy-Maszák, 1994, Szabó, 1994). Representatives of this intellectual tapestry not only were decisive in culture, but many of them entered politics during the short-lived revolutionary governments after the First World War.

In summary: before World War I Hungary was not just close to the scholarly space where psychology was formed, but it was a constituent part of this creative space.

Social demands of modernization and cultural-intellectual preparedness met each other and produced a developmental trajectory, which resulted in a kind of psychology rather typical in Central Europe. No language or cultural barriers existed to the exchange of ideas in the region, as the working language of the Hungarian academic community was still German. Hungarian scientists had original contributions and they were in personal contact with leading European scientists. Following these beginnings, history took a dramatic turn in the aftermath of World War I, and psychology was not exempt from these events. Following the collapse of Austria-Hungary, Hungary became, in many ways, a different country than it was before the war. 


\section{Between the two World Wars \\ Cataclysms in the aftermath of World War I}

We have to digress briefly into the chaotic and catastrophic events around the end of the war at this point. Armed hostilities of World War I ended by November 1918, when Germany signed the armistice with the Allied Powers. Fighting, however, continued along the Hungarian border, where the seceding nationalities aspired to realize their territorial claims. The economic situation deteriorated and following strikes and uprisings a revolution broke out in October. A liberal socialist government took over and terminated its union with Austria, proclaiming the Hungarian Democratic Republic on October 31, 1918. Hungary soon had to face the Czechoslovak, Romanian and Serbian armies crossing the borders and occupying significant parts of Hungary, in order to carve out territories for their to-be established nation states. When the republican liberal government collapsed, the Communist Party of Hungary (led by Bela Kun) grabbed power. ${ }^{7}$ In the spring of 1919 Hungary was the second country in the world after the Russian Soviet State to be ruled by the dictatorship of the proletariat, which lasted for 133 days. The Hungarian Soviet Republic was soon followed by the anti-communist-conservative Horthy regime. On June 4, 1920, Hungary was forced to sign the Trianon Treaty. These events, which exerted a profound influence on the 20th-Century Hungarian psyche, had ramifications for psychology.

In November 1918 (the last month of the war) Ferenczi organized the Fifth International Psychoanalytic Congress in Budapest, where he was elected president of the International Psychoanalytical Association. In spite of the hectic situation government officials of the Hungarian Republic attended the Congress because of the general interest in the psychoanalytic treatment of war neurosis. The liberal government was sympathetic to reforms in higher education, and when medical students demanded in a petition that Ferenczi get an academic position at the Pázmány University, a nomination procedure started. The university council was against it, but after the communist take-over the Bolshevist government granted Ferenczi a professorship and approved the establishment of a Department of Psychoanalysis against the will of the Council of the Medical Faculty (Erös, 2009, 2011, Mészáros, 1998, Moreau-Ricaud, 1996). At a time when psychoanalysis was at the periphery of international academic life and nowhere in the world was it present in universities, the short-lived Hungarian Soviet Republic presented an unprecedented opportunity for psychoanalysis to establish itself as an academic discipline.

During its brief existence the Communist state took dictatorial measures to raise the poor, abolish private property, nationalize banks, industrial and commercial enterprises, housing and cultural institutions, liquidate the Church, and collectivize agriculture. At the same time they had to fight the Czechoslovak, 
Serbian and Romanian troops entering Hungary. Radical intellectuals, many of them of Jewish origin, were attracted to social reforms and became leaders in the liberal and the communist governments. Jewish involvement in the shortlived Hungarian Soviet Republic was significant: the great majority of people's commissars (ministers of the communist government) were of Jewish descent - among them Jenő Varga, an economist and psychoanalyst, who was commissar of finance, and philosopher György Lukács, who was commissar of culture (Gyurgyák, 2001, Patai, 1996).

Measures were taken with an iron fist, including hostage taking from the civilian population and daily executions by revolutionary tribunals to prevent counterrevolutionary attempts. Even Pál Ranschburg was arrested because formerly he received military officials in his office (Ranschburg, 2013). The communist rule was rejected by the great majority of the population, including the substantial number of middle- and upper class Hungarian Jews, involved in banks and commercial and industrial establishments. In four months the communist regime lost all of its social support and military power, and Romanian troops entered Budapest in August. Communist leaders fled Hungary and right wing former admiral Miklós Horthy took power and signed the Treaty of Trianon. A brief period of "white" (anti-red) terror followed the collapse of the communist regime, with a campaign of revenge, torture and murder. At Pázmány University both Ferenczi and Révész were dismissed (along with other professors who could be associated with the revolutionary regimes) and the initial steps taken by them to organize a psychoanalytical and an experimental department were disrupted.

The heavy involvement of Jewish intellectuals in the liberal socialist and communist regimes helped spread the notion of a Jewish-Bolshevik conspiracy. Fearing the worst, the father of Edward (Ede) Teller, who later became a famous physicist, told his son that anti-Semitism was inevitable because "too many of the communist leaders are Jews" (Nye, 2011, 15). Indeed, anti-Semitism intensified. Although atrocities were fundamentally over by the end of 1920, the remaining anti-Semitic atmosphere (marked by a "numerus clausus" law which restricted the number of Jews entering universities) sparked the first wave of post-war Jewish emigration. Hungarians' emigration was actually already in progress, however, in the 1920 s emigration was a choice increasingly taken by intellectuals. As Szegedy-Maszák put it: "Hungary was about to lose one of her finest generations" (Szegedy-Maszák, 1994, 21).

Among those who left the country were young people who later reached extraordinary achievements in science, in the United States: Noble laureate radio chemist György (Georg von) Hevesy, contributor to research on nuclear chain reaction, physicist Leó Szilárd, who patented the idea of atomic reactor with Enrico Fermi, Noble laureate physicist Eugene (Jenő) Wigner, contributor to nuclear physics and quantum mechanics, theoretical physicist Edward (Ede) Teller, 
colloquially known as the father of the hydrogen bomb, mathematician and polymath János (John von) Neumann, known as the father of the modern computer and game theory, physicist Tódor (Theodore von) Kármán, known as the father of modern aerodynamics and supersonic flight, and the first director of NASA's Jet Propulsion Laboratory, and Nobel laureate physicist Dénes Gábor, inventor of holography. Later in science folklore this group was called "the Martians", because it was joked that their close connection to each other, their strange and heavy Hungarian accent, and their seemingly superhuman intellect was explained by their coming from Mars (Marx, 1994, 2000).

The phrase "Martians" referred mostly to those of the above, who later worked on the development of the nuclear bomb in the Manhattan Project, between 1942-46. However, the emigrant group was much larger and included prominent scientist from various fields. Amongst them were: Arnold Hauser art historian, George (György) Lukács philosopher, Karl (Károly) Mannheim father of sociology of knowledge, Michael (Mihály) Polányi physical chemist, economist and antipositivist philosopher of science - to mention some of the most famous. These scientists, who had already known each other from Hungary (Leo Szilárd and Ede Teller even attended the same gymnasium), never ceased to maintain their Hungarian network, and kept their Hungarian identity (Hargittai, 2006).

Emigration caused a severe loss in psychology, as well. About one third of the Hungarian Psychoanalytic Society left the country, among them Sándor Radó (who was analyzed by Wilhelm Reich and Heinz Hartmann in Berlin, and later became director of the New York Institute of Psychoanalysis) and Melanie Klein, who was not of Hungarian origin, but lived in Budapest at that time and was analyzed by Ferenczi (Mészáros, 2009). Most of them left for Berlin, the rapidly expanding cultural and scientific capital of the Weimar Republic (Nye, 2011). Among the immigrants was Géza Révész, appointed head of the to-be-organized department of experimental psychology at Pázmány University, who settled in the Netherlands and became an outstanding researcher of the psychology of hearing and music (see endnote 6).

Besides emigration, Hungary had to face immense difficulties caused by the Treaty of Trianon. The Austro-Hungarian Monarchy was an integrated and interdependent economic unit. In the post-war situation the fragmented, protective economies of the successor states took over and the whole region faced a deep recession. Post-Trianon Hungary lost over $70 \%$ of its public roads and its railway system, more than $50 \%$ of its industrial plants and banking institutions, lost its markets for the agricultural products and almost all of the resources of raw materials. Out of the $30 \%$ of ethnic Hungarians who found themselves living outside of Hungary, several hundred thousands left their homes and immigrated into Hungary where many lived in railway carts for years, for lack of housing. While the successor states regarded the Treaty of Trianon an act of righteousness, for 
Hungarians it was felt as disastrous and caused lasting bitterness and revisionism, which was a dominant theme of political discourse between the two wars (Sugar, Hanák and Frank, 1994).

Territorial dissection caused significant problems in the cultural-educational infrastructure, as well. Major cultural centers (Kassa, Pozsony, Nagyvárad, Kolozsvár, Marosvásárhely, Brassó) were now outside of the borders. Two of the major universities - one in Kolozsvár (Cluj) and the other in Pozsony (Bratislava) did not belong to Hungary anymore. The Romanian troops entered Kolozsvár in November 1919 and overtook the university by military force, along with Lechner's Clinic (Iványi, 2008). Kolozsvár University, a university of great practical and symbolic importance to Hungarian academic life, ceased to exist and, through a torturous process, had to "repatriate" in the newly defined Hungary. The geographically close Hungarian city, Szeged volunteered to take in the refugee university. Lechner, who also lost his son on the front, moved to Szeged to rebuild his Clinic there, but soon he died.

\section{The Budapest School of Psychoanalysis in the consolidated Horthy regime}

After the fall of the Hungarian Soviet Council Ferenczi was dismissed from the professorship and even expelled from the Medical Society. Jewish students were beaten at the Medical Faculty, and all of the Jewish professors were dismissed. The first emigrants (among them Michael and Alice Bálint, and Franz Alexander) left for Berlin, and, in the meantime, Anton von Freund, the financial patron of Hungarian psychoanalysis, died. Ferenczi himself considered emigrating, but in a letter of March 15, 1920, Freud advised him to stay, in order to prevent the total collapse of psychoanalysis in Hungary (Moreau-Ricaud, 1996). By the mid1920's atrocities basically stopped and due to the political and economic consolidation of the Horthy regime under Prime Minister István Bethlen life got back to normal. Ferenczi stayed and due to his efforts the Hungarian Psychoanalytic Society kept working, even growing, and introduced novel directions in psychoanalysis. The decade between the mid-1920's and mid-1930's became the heyday of Hungarian psychoanalysis.

By that time Ferenczi grew more independent of Freud and introduced innovations both in therapy and theorizing. Eventually, he departed from Freud in questioning the hierarchical nature of the relationship between the analyst and the analyzed and emphasizing the interpersonal dimension of the analyst-patient relationship. He also questioned the sexual interpretation of the emotional needs of the child and emphasized the importance of the parent in healthy development. Although later these ideas became important sources of post-Freudian psychoanalysis (specifically, the object relations school), at that time they were consid- 
ered highly controversial by Freud and members of the international psychoanalytic movement (Vikár, 1996). By the 1930s personal and professional tensions caused a rift in the Ferenczi-Freud relationship. Ferenczi became somewhat of an "enfant terrible" in the psychoanalytic movement (Bergmann, 1996, Haynal, 1996, Nemes, 1996, Keve, 2012). His name was also tainted by the unfounded stigma of mental illness, suggested by Ernest Jones. Ferenczi continued his "dissident" career, visited the United States for a couple of months in 1926-27 at the invitation of the New School for Social Research, but suffered a sudden death of pernicious anemia in 1933. In the history of the international psychoanalytic movement his work was neglected, in spite of Freud's vow in his farewell speech at Ferenczi's death that he would not be forgotten (Nemes, 1986, Keve, 2012). Nevertheless, Ferenczi was highly effective in generating a dedicated and talented group of disciples who eventually came to be known as the Budapest School (Harmat, 1995, Mészáros, 2009, 2012).

In the late 1920s and 1930s, when anti-Semitism became more and more brutal in Germany and Austria, the psychoanalytic movement was freely functioning, even flourishing in Budapest. In 1931 the Hungarian Psychoanalytic Society established the Psychoanalytic Polyclinic in Budapest. This was the second to the Berlin Polyclinic, which opened in 1920, after plans in setting up the first polyclinic in Budapest were crushed by the political events. The Polyclinic was a training institute but also a place for scientific meetings, courses organized for mothers, teachers and doctors, and outpatient care for children and adults including those who could not afford paying. Psychoanalysis maintained an extensive following among the lay public, and kept influencing literary life. Great Hungarian literary figures (Mihály Babits, Géza Csáth, Attila József, Dezső Kosztolányi, Sándor Márai, Antal Szerb) were deeply influenced by Hungarian psychoanalysis, which by that time presented a group of significant personalities and novel ideas. The main originality and cohesion of the group came from drawing on Ferenczi's shift from the Oedipal conflict to the early mother-infant dual unit (Mészáros, 2009, Nemes, 1986).

After the death of Ferenczi, Mihály (Michael) Bálint (1896-1970), one of his most significant followers assumed a leading role in the movement and became the head of the Polyclinic. Bálint, who in the 1920s worked in the Department of Biochemistry of the Wilhelm Kaiser Institute in Berlin, kept his interest in general medical practice and used psychoanalysis in the training of doctors. This work led to the group-discussion technique, later called "Bálint groups", for medical doctors to analyze the psychodynamic factors in the doctor-patient relationship. Following Ferenczi's interpersonalist approach he considered "primary love" between mother and infant the basis of healthy emotional development, and the breakdown of these relations - which he called the "basic fault" - the source of neurosis. In letters to Freud Ferenczi mentioned Bálint's case study of a heart 
condition caused by somatic transference, as well as István Hollós's publication in which he proposed humanistic psychiatry (Hollós was chief doctor in the National Psychiatric Hospital [Lipótmező] where he reformed treatment of patients and introduced psychoanalysis in treatment methods [Moreau-Ricaud, 1996]).

Another leading figure, Imre Hermann (1889-1984) was looking for the biological grounding of psychoanalysis, relating the psychoanalytic instinct concept to the ethological notion of instinct. Hermann, who was initially trained in experimental psychology (by Géza Révész), followed primate studies in the 1920s and recognized that the instinctual clinging of the baby ape to the mother is preserved in the human infant. He proposed that mother and infant create a biological unit and physical closeness transforms into emotional attachment. This was antedating the work of Bowlby (who then inspired Harry Harlow's work with rhesus monkeys), Mahler and Winnicott (Geyskens, 2003).

While all the distinguished psychoanalysts who worked at that time in Budapest cannot be acknowledged here, two more pioneering figures must be mentioned. Géza Róheim (1891-1953), trained originally as an anthropologist, trying to find an alternative to "consulting room analysis", traveled in 1929 to the Australian Aborigines, New Guinea and Mexico, to pursue psychoanalytic-anthropological studies - the first of its kind in psychoanalysis (Moreau-Ricaud, 1996). Lipót (Leopold) Szondi (1893-1986) developed a unique approach that combined genetics and psychoanalysis. Initially also working with Pál Ranschburg, later succeeding him as the director of the reorganized research lab at the Budapest College of Special Education. Meanwhile he developed a unique theory of ,fate analysis", which holds that a person's life (destiny) unfolds in a series of elections realized in choices of occupation, friends, partners, and these life decisions implicitly select illnesses and ultimately the way of death. His concept of the familial unconscious describes the role of the family ancestry in grounding the choices (Gyöngyösiné Kiss, 1996, 2010).

By that time psychoanalysis was a well-established movement, with its own infrastructure. Adlerian influences also found their way in Hungary, and in 1927 the Hungarian Association for Individual Psychology (Magyar Individuálpszichológiai Egyesület) was founded (Kiss, 1991). For mainstream culture psychoanalysis still was as a "suspicious outsider", however, its popularity grew in certain urban middle class circles. Psychoanalysis became known for its theory and clinical work with children, but it also attracted politically minded individuals who took it as an intellectual revolt and infused it with anti-capitalist sentiments (Kovai, 2015). 
The strengthening of the psychology profession in the inter-war decades

With a multi-party system without a universal secret ballot and a relatively free press, Hungary under Regent Horthy was a restricted democracy with semi-feudal features, such as maintaining the concentrated ownership of land and the exclusion of poor people from political elections by a restrictive voting law. ${ }^{8}$ Interwar Hungary was a Christian conservative nationalist country, where, as observed by Szegedy-Maszák (1994), the cultural atmosphere radically changed compared to the pre-war period. Bourgeois liberalism and all sorts of radicalism were discredited. From a geographically large, multinational, multicultural country with a large number of urban centers Hungary became a small country, less open to cross-cultural influences and modernity. Values of the national past and peasant culture became dominant, and a fatal dichotomy ensued between the proponents of urban culture (dominantly Jewish and German) and the countryside's rural culture (for a deeper discussion see e.g. Szegedy-Maszák, 1994).

The Horthy era did see some social achievements. By far, reforms in the educational system, championed by minister of culture Kuno Klebelsberg in the 1920 's, brought the most significant changes. Klebelsberg realized that for Hungary the way to compensate losses was to develop its culture and educational system. At his initiative 3,500 elementary school classrooms were built in five years in the Hungarian country-side to fight analphabetism (Palló, 2007). He initiated reforms at all levels of education and began the modernization of universities. He initiated a new university in Szeged, where the expelled university from Kolozsvár could move, and another university in Pécs, where the expelled university from Pozsony (Bratislava, Slovakia) could relocate. Klebelsberg also supported the Hungarian Academy of Sciences, multiplied the number of research institutions and introduced a scholarship system in science education. He also contacted the Rockefeller Foundation (which started its activities in Hungary right after World War I) to extend support for Hungarian science (Palló, é.n.). Klebelsberg also supported the child study movement, specifically the reform school (called the "Új Iskola"/"New School") of Ms. Domonkos Emma Löllbach, a former student of László Nagy (Sáska, 2008).

The Child Study movement kept growing between the two wars, and was joined by some well-known Christian priest psychologists, such as Dezsö Várkonyi Hildebrand, who also was the chair of the "Educational-Psychological Institute" in Szeged. The Benedictine "priest professor" Dezső Várkonyi Hildebrand (1888-1971) was invited to Szeged in 1929 to set up the first psychology institute at a Hungarian university. Before this engagement, he spent two years at the Sorbonne in Paris studying the work of Jean Piaget, Eduard Claparede, and Henri Bergson. At Szeged he introduced a psychology that focused on the pedagogical aspects of child development, emphasizing the role of action (Völgyesy, 
1995, Csomortáni, 2009). He was in contact with Ms. Domonkos's New School in Budapest, but also helped set up an experimental elementary school in Szeged, and launched the journal Cselekvés Iskolája ("The School of Action"). Várkonyi had a research laboratory in his Institute established with the support of the Rockefeller Foundation, and was surrounded by doctoral students. He became one of the leading figures of Hungarian psychology, serving as the chief editor to the Hungarian Psychological Review, and later as the president of the Hungarian Psychological Association (Csomortáni, 2009).

Besides the Child Study movement, the Hungarian Association for Individual Psychology also took great interest in educational psychology, and contributed to the extension of educational counseling services. Psychology reacted to the needs of changing family life: this was the time when families started to down-size the number of children and an increasing number of mothers entered the work force (Lisznyai, 1999). Individual psychologists offered their services for free, to help in a situation which was characterized by István Máday, the leader of the Association as follows: "Due to the present existential problems parents manage their children in a nervous and impatient way which may cause behavior problems or illness in early childhood. The spreading social problems related to children - alcoholism, prostitution and other immoral manners - push children towards maladaptive models of coping." (Cited by Lisznyai, 1999, 170). In the 1930s a number of child counseling offices opened, following the first one that worked within the framework of the National Child Protection League (Gyermekvédö Liga). The Education Department of Budapest popularized these services in every school, thus this opportunity was well known for parents (Lisznyai, 1999).

Hungarian psychology at large enjoyed a time of substantial development. Society increasingly needed psychological expertise and in the wake of the worldwide economic crisis in the early 1930s, applied psychology was supported by the government also as part of social policy to help maintain social peace. Importantly, in 1928 the Hungarian Psychological Association was formed by Pál Ranschburg and others, and the journal Hungarian Psychological Review ("Magyar Pszichológiai Szemle") was launched. In addition to Szeged, psychology was academically institutionalized in universities in Debrecen and in Budapest. In 1931 the Royal Hungarian Child Psychology Institute was established in Budapest under the leadership of János Schnell, Ranschburg's student. At the Institute a well-equipped psychological laboratory focused on the differential diagnosis of the handicapped and new methods of "healing pedagogy", in which leading experimental psychologists, such as Pál Ranschburg and Lipót Szondi also participated (Gordosné, 2013). In 1927 Lipót Szondi was entrusted to lead the research laboratory at the Teacher Training College for Special Needs Education. Here he created a hub of research, involving dozens of co-workers, and a close-knit intellectual "family" consisting of thirty-some members, who met in his apartment on 
a regular basis. (Bürgi-Meyer, 1996, Kovai, 2015). 9 "Psychotechnical" laboratories were set up in several factories for vocational counseling and aptitude testing (Völgyesy, 1995, Kiss 1983). These laboratories were part of the effort to train a work force, in the style of Taylorism, for the increasing needs of the industry (Kovai, 2015).

In Budapest, it was Pál (Paul) Harkai Schiller (1908-1949), who realized in 1936 what Géza Révész wished to accomplish 17 years earlier: setting up an institute for experimental psychology at the Péter Pázmány University. Harkai Schiller, born with a Catholic background, graduated in 1930 in Budapest, worked in Ranschburg's Lab, and then went to Berlin to cooperate with the Gestalt psychologist Wolfgang Köhler. On his return he became a highly effective organizer: he set up institutions for aptitude testing in the Hungarian Army and in the Hungarian Railways Company. He founded and edited a book series "Lélektani tanulmányok" ("Studies in Psychology"). He was, however, also a remarkable experimentalist in comparative psychology and a theoretician in psychology. In the 1930s and 1940s he developed an original theoretical synthesis based on the ideas of Aristotle, Jakob von Uexküll, Franz Brentano, Wolfgang Köhler, Karl Bühler and Kurt Lewin, arguing against Cartesian dualism. Building this synthesis around the importance of action he developed an "action theory of behavior" (Dewsbury, 1994, 1996, Marton, 1996).

An intellectually and artistically gifted strong woman character of this era, the deeply Catholic Valeria Dienes (1879-1978) was the first woman to get a doctoral degree at the Péter Pázmány University, where she studied mathematics, philosophy and esthetics. She worked with Henri Bergson in Paris, then translated and mediated Bergsonian ideas and helped the propagation of French educational functionalism (Pléh, 2005). She also launched an artistic dance movement called "orchestrics", based on her own systematic study of human movement (Jakabffy, n.d.). In the meantime, the biophysicist György (Georg von) Békésy (1899-1972), who later won the Noble prize in physiology in 1961 for his work on the function of the cochlea, quietly worked at the Research Center of the Hungarian Post Office, then at the Department of Physics at the Pázmány University of Budapest (Pléh, 2005).

In the 1930's nationalist and anti-Semite political forces became gradually more and more influential. Such views started to appear in psychology, dressed in prevalent eugenic and racial biological frameworks, represented by lesser know psychologists. However, not the Nazi type racial theory was most influential, but a nationalist discourse focusing on the concept of national character (Erős, 2015).

At this time Hungary's foreign policy moved closer to Nazi Germany, driven by the logic of economic dependence and territorial revisionism. Following World War I, Hungary got deeply indebted so it could stabilize its economy and pay reparations imposed upon the country in the Treaty of Trianon. During the Great 
Depression in 1931 Hungary became insolvent, and an economic treaty with Germany meant the only geopolitically available solution to maintain the economy (Sugár, Hanák, Frank, 1994). Hungary grew more and more dependent on Nazi Germany, which was, at the same time, its only hope to aid territorial revision.

Hungary had a mixed relationship with Hitler's Germany. The two Vienna Awards - arbitrations in 1939 and 1940, when Germany and Italy returned territories to Hungary - seemed to justify revisionist hopes. However, a substantial Anglo-Saxon orientation was also present in the political elite. In his memoirs John Flournoy Montgomery, the American ambassador at the time, described Hungary as the "unwilling satellite" (Montgomery, 1947), referring to the fact that many in the political and military elite, including Regent Horthy, realized how dangerous the alliance with Hitler was. Nevertheless, they were unable to change course and Hungary drifted more and more to the side of Germany. After the Anschluss of Austria, Hungary introduced in 1938 the first Jewish Law, which established a quota system to limit the participation of Jews (defined on the basis of religion) in the economy, in the press, and among physicians, engineers and lawyers to $20 \%$. The Second Jewish Law in 1939 defined Jews by race, thereby affecting those who had formerly converted from Judaism to Christianity. In addition to these restrictions, employment at any level of the government was forbidden. Jews could not be editors at newspapers, and even private companies were forbidden to employ more than $12 \%$ Jews. Some quarter of a million Hungarian Jews lost their income (Patai, 1996).

These laws, along with increasing anti-Semitism, evidently affected psychologists with a Jewish background, and, since many of the leading psychologists were Jewish Hungarians, these measures had ramifications for the whole psychology profession. From 1937 on, the secret police started to watch psychoanalytic meetings. Due to the Jewish Laws Lipót Szondi was dismissed from his directorial appointment at his laboratory and was even banned from private practice, along with other Jewish psychoanalysts. Pál Ranschburg (who previously converted to Christianity) was excluded from the Chamber of Hungarian Physicians (Ranschburg, 2013).

In January 1939 István Hollós, president of the Hungarian Psychoanalytic Society turned to the International Psychoanalytic Association, requesting help for emigration (Mészáros, 2012). Right after the Anschluss the American Psychoanalytic Association established a committee to aid the emigration of European analysts - to counter the restrictive immigration laws of the US and the fear on the part of American authorities of importing leftist-communist ideology. After the first wave in the early 1920s, a second wave of emigration of intellectuals took place between 1938 and 1941. Among the second-wave immigrants were Michael (Mihály) Bálint and his wife, Alice Bálint, Géza Róheim and the 
27-year-old Dezső (David) Rapaport, student of Harkai Schiller, who fulfilled his career in the United States (Mészáros, 2009).

Between 1938 and 1941 about 150 analysts arrived into the United States from Europe, causing some tensions in the profession. As pointed out by Mészáros (2012), the émigrés perceived themselves as representatives of the authentic tradition of psychoanalysis and had a sense of superiority over their American colleagues, who, in turn, thwarted the Europeans' practice and wanted them to conform to regulations prevalent in the US. In spite of these difficulties, Hungarian émigré psychoanalysts of the first and second waves were typically successful. Sándor Radó became the first educational director of the New York Psychoanalytic Institute established in 1931, and was effective in introducing psychoanalysis into the curriculum at Columbia University. Franz (Ferenc) Alexander, the first graduate of the Berlin Psychoanalytic Institute, and a person Freud once considered to be one of the strongest hopes for the future, was invited to be the first director of the Chicago Institute of Psychoanalysis in 1932 and became the emblematic figure of psychoanalytically minded psychosomatic medicine. David Rapaport became the organizer and head of the Research Department at the Menninger Clinic in Topeka, Kansas. Several émigrés became training analysts. Presidents of the New York Psychoanalytic Society included Sándor Lóránd, Robert Bak, Margaret Mahler and Andrew Pető (Mészáros, 2009).

Others stayed in Europe. Mihály Bálint became Director of the Child Guidance Clinic in Manchester, England, then worked at the Tavistock Clinic in London and became president of the British Psychoanalytical Society in 1968. In addition to "Bálint groups", he also earned fame for his innovative "focal psychotherapy". Szondi worked and trained students in Zurich and spent four decades of prolific work there before his death in 1989. Other psychoanalysts settled in places as far as New Zealand and Ceylon (Sri Lanka) (Mészáros, 2012).

Those who stayed at home eventually had to face persecution of the worst kind, due to the tragic turns of events. Becoming aware of secret negotiations by the Hungarian government with the British and the Americans, Hitler ordered the occupation of Hungary by German troops in March 1944. Adolf Eichmann came to Hungary to organize the deportation of the Jews and the Gipsy population - in two months 437,402 people were deported to Auschwitz, mostly from the country-side. In August Horthy stopped deportations and on October 15th he announced that Hungary signed an armistice with the Soviet Union (in September the Soviet Army had already crossed the Hungarian border). The armistice, however, never took affect. The Germans kidnapped Horthy's son and forced him to appoint Ferenc Szálasi, leader of the Hungarian fascist Arrow Cross Party, the Prime Minister of Hungary. In cooperation with the Nazis Szálasi stepped up the effort to execute the deportation of the Jews in Budapest, who were by that time forced into the ghetto (Sugar, Hanák and Frank, 1994). 
In 1944 Ranschburg had to move into the ghetto. By the help of friends he narrowly escaped deportation. Lipót Szondi, was, however, deported from Budapest to Bergen-Belsen with his family. Eventually they were released as a result of a deal between Rudolf Kastner, a Jewish-Hungarian lawyer who, on behalf of the Budapest Aid and Rescue Committee, negotiated with Adolf Eichmann to allow a number of Jews to escape, in exchange for gold and cash. Pál Ranschburg and Imre Hermann stayed and survived the worst months of the persecution in Budapest, in hiding.

\section{After World War II \\ Psychology under the harshest years of communist dictatorship}

After World War II there was a resurgence of activity in Hungary and great optimism to rebuild the country and create a new democratic system. Psychology was part of this revitalization. Initiatives were taken to recreate the institutional basis of psychology, for example, the nationwide network of State Child Psychology Stations. Journals and professional organizations were renewed. The Hungarian Psychoanalytic Society started its activities again ${ }^{10}$, with Imre Hermann as president. Psychology and psychoanalysis were once again introduced in the university. Psychoanalysts were very active politically, in fact, many of them held key positions in the reorganization of the mental health system and education (Mészáros, 2012).

Ferenc Mérei (1909-1985) returned to Hungary from Moscow, and became a leading figure of psychology and a leader in "NÉKOSZ" - a network of "People's Colleges" established after the war, in order to promote social mobility of the underprivileged youth. ${ }^{11}$ Mérei got his degree at the Sorbonne in the early 1930's, and became a follower of the child psychologist Henri Wallon. Wallon became a communist, and Mérei, too, joined the French Communist Party in 1930. Between 1938 and 1940 he worked with Lipót Szondi at his laboratory at the Special Education Teacher Training College in Budapest, researching the role social rules played in, however, later on he was expelled due to the second Jewish Law. He was taken to forced labor service, but he escaped and joined the Soviet Army. Upon returning Mérei was appointed the head of the Budapest Institute of Psychology (Fővárosi Lélektani Intézet) in 1945. Here he conducted internationally acclaimed experimental work on the "collective experience" of groups (Bagdy, Forgács and Pál, 1989, for more on Mérei see Borgos, Erős and Litván, 2006).

In the shadow of the Soviet Army occupying Hungary, aspirations for democracy and freedom were put to an end in 1949. As a result of the Soviet military occupation and the Yalta agreement between the Allies and the Soviet Union it was actually ordered that Hungary would remain under Soviet influence. Many of 
the Communist leaders of 1919 returned from Moscow, and with Soviet help the Hungarian Communist Party grabbed power and introduced a Stalinist dictatorship with Mátyás Rákosi as leader. The country was reorganized according to the Soviet model: by 1950 the state had full control of the economy and the society, including ideology and the academic world (for a detailed discussion of this period see Golnhofer, 2006, Kovai, 2015).

The communist system worked to uplift the working class and replace the former ruling classes. After the Horthy regime, for many this meant social mobility and social justice. However, it soon became clear that the country had to pay for these social advancements with a Soviet-style terror: an estimated 2,000 people were executed, over 100,000 were imprisoned, about 44,000 put in forcedlabor camps, and an estimate of 15,000 reactionary "class enemies" - former aristocrats, industrialists, military leaders and other upper- and middle-class people - were deported from their homes to live in villages and perform agricultural labor (Patai, 1996).

For the surviving Jewish population ${ }^{12}$ the situation was precarious. Zionism had its call: between 1945 and 1949 approximately 45,000 Jews emigrated, most of them into Israel ${ }^{13}$. Other Holocaust survivors put their faith into the new regime, hoping that the communist system will abolish anti-Semitism and introduce a just society. The majority of the communist leaders, including the secret police, were of Jewish origin, including Mátyás Rákosi himself. On ground that the Jewish population was exempt from the infection of fascism, people of Jewish origin were trusted by the Rákosi regime and were often put in leading positions. Ironically, while communists of Jewish origin typically stopped perceiving themselves as Jews, in line with the ideology of internationalism, the wider population still viewed them as Jews. In addition to this, a number of factors maintained antiSemitism - significant was that many Hungarians took possession of the assets of deported Jews, or were just idle by-standers of the deportations, and were therefore negatively affected by seeing Jewish people coming back from the camps and taking up leading positions (for a deeper discussion see Gyurgyák, 2001).

Ideological control meant that views not in line with the official interpretation were severely persecuted. The Trianon issue became a taboo in the name of communist internationalism. Paradoxically, the issue of Hungarian participation in the genocide and all related "Jewish questions" became a taboo, too. ${ }^{14} \mathrm{In}$ 1945 the painful analysis of Hungarian participation in the genocide began and until 1948 this issue was at the center of public debate. A group of psychologists, many of them Holocaust survivors, published a book by the title: „The mental epidemics of the recent past. The disordered group mind and its cure" (Gleimann, Harkai Schiller and Herman, 1945). However, after the Communist Party came to power, such discussions came to a halt, because the official line denied the relevance of the special situation of the Jewish population, presenting all of history 
as the struggle between the anti-Fascist working class and the Fascist bourgeoisie (Patai, 1996). The Communist Party was keen to abolish the past while building the future, and in this framework much of Hungarian history was reinterpreted or purged from collective memory. Importantly, taboos were internalized not only by those who identified themselves with the regime, but also by the wider population.

These conditions presented a complex situation for psychologists. Emigration was, again, an option. Pál Harkai Schiller and his wife left Hungary in 1947 and went to work at the Yerkes Laboratories of Primate Biology in Orange Park, Florida, at the invitation of Karl Lashley. He spent two proliferate years there before his untimely death in a skiing accident in 1949, following his visit to B.F. Skinner at Harvard University (Dewsbury, 1996). Gyögy Békésy also moved to the United States. Those who stayed had to put up with conditions that were modeled after the state of Soviet psychology.

In the 1930's the Soviet Union went through a new wave of terror (also called the Great Purge) that Stalin initiated in order to crush all resistance. ${ }^{15}$ This brought along the "Bolshevization" of science, which meant a sharp turn in academic life towards the persecution of "pseudo-Marxist" and "bourgeois" elements. The formerly popular mental health movement and psychotechnics were condemned for the "uncritical use of tests of bourgeois authors" (Joravsky, 1989, 339). In July 1936 the Party Central Committee accused Soviet pedology for willfully demonstrating the defects of children of worker and peasant family background - what meant the end of testing. According to the voluntaristic Party line children's capabilities were only shaped by pedagogical means, and biological or social circumstances did not play a role. Child psychology was subordinated to Marxist pedagogy (Joravsky, 1989).

Up until October 1932 Pavlov had a mixed evaluation by Soviet officials. Some praised his "enormously important scientific work", even described his theory as "a weapon from the iron arsenal of materialism" (Joravsky, 1989, 380), while others held him to be a reactionary. As Joravsky points out, Marxist intellectuals had a hard time squaring Pavlov-style physical materialism with Marxian dialectical historical materialism, and both with the Bolshevik insistence on the supreme power of communist conscious will. This situation, however, sharply changed when Stalin decided to elevate Pavlovism to the status of a unifying theory and the only acceptable Marxist-Leninist psychology. Before his 1936 death Pavlov also changed his attitude towards the Soviet regime: he gave up his internal exile and declared open support for the communist fatherland (Joravsky, 1989). Following World War II Russian chauvinism greatly strengthened and the supremacy of Russian science became a doctrine. Stalin himself intervened in matters of science and in 1947 initiated the purge of scientists of Jewish origin under the banner of fighting cosmopolitism. This led to the attack of the distin- 
guished psychologist Sergey Rubinstein, among others. Such was the state of affairs when Soviet psychology became relevant for the course of events in Hungary.

In Hungary the first attack came on psychoanalysis. After the Third International Mental Hygiene Congress in London in 1948, where several Hungarian psychoanalysts participated, Dr. István Tariska (neurologist-psychiatrist and a high ranking administrative official) published an article in which he denunciated psychoanalysis for spreading retrograde ideas. He claimed that the Mental Hygiene Congress in London showed that imperialism "has tamed psychoanalysis into its own private psychology" (cited by Mészáros, 2012, 98). Tariska also suggested that communist psychoanalysts were with the Party only because of being Jewish. Lilly Hajdu and Imre Hermann, successive presidents of the Hungarian Psychoanalytic Society, both Jewish, and members of the Hungarian Communist Party, wrote a letter to philosopher György Lukács, who was then academician and member of the communist Parliament ${ }^{16}$ asking for his protection, while claiming that they themselves agreed with the Marxist-Leninist critique of psychoanalysis. The answer made it clear that the Communist Party considers psychoanalysis to be "socially reactionary". Hence, after conforming to Party discipline, Hermann and Hajdu suggested to members that the Hungarian Psychoanalytic Society be dissolved. The Society, which legally functioned even under German occupation, and existed continuously since 1913, was dissolved (Borgos, 2009, Mészáros, 2012, for more details on Lilly Hajdu see Borgos, 2009). This event was a major excercise in the "self-cleaning" of psychoanalysis - a practice in which the Communist Party expected its members and various communities to engage in self-criticism (Kovai, 2015). Psychoanalysis could no longer be practiced openly until the mid-1960s.

Another attack came in 1949, in the year when László Rajk, Minister of the Interior in office, and himself an organizer of the communist secret police under Rákosi, was accused of being a Titoist spy in a show trial and was executed. In the general atmosphere of terror a resolution of the Hungarian Communist Party condemned pedology in 1949, modeled after the 1936 Party resolution in the Soviet Union. Psychology was meant to become an ancillary science of socialist pedagogy (Sáska, 2008). Professors with the wrong kind of class background, or with a Catholic background (such as Dezső Várkonyi Hildebrand), were dismissed from employment. But as the case of László Rajk shows, paranoid communist policy was looking for enemies also among those who were committed communists. ${ }^{17}$ Ferenc Mérei, himself a communist, who was shortly before awarded a high medal (Kossuth Prize) for his pedagogical work, was observed by the secret police (Litván, 1999), and in 1950 he was fired and his institute was liquidated. The absurdity of the situation is revealed by the fact that shortly before this Mérei himself, as "the" leading psychologist of the country, condemned psychology and 
pedagogy for "psychologism", which referred to the charge that the representatives of these practices did not pay enough attention to the mission that pedagogy and psychology has to fulfill in shaping the new generations who will build socialism (Kovai, 2015, gives a detailed presentation and analysis of this era).

The Hungarian Psychological Association and its journal were shut down. Although the training of psychologists at the university ceased to exist for 14 years, nevertheless psychology was still represented in a small number of institutions. The Institute of Child Development, the descendent of the Ranschburg institute, was attached to the Hungarian Academy of Sciences in 1955. At the National Neurological and Mental Hospital (Lipótmező) psychoanalyst Lilly Hajdu became director and she was able to set up a new Work Therapy Institute. The Psychology Institute in the Special Education College also survived under the leadership of Flóra Kozmutza, although with a research profile on topics like the character improvement of workers. Another refuge of psychology existed in the Vocational Aptitude Testing Station at the Hungarian Railway Company, and another at the No.1 Child Clinic in Budapest, led by Lucy Lieberman (Máriási, 2015).

The Department of General Psychology at the Budapest university represented the only remaining stronghold for academic psychology, under the leadership of Lajos Kardos, one time student of Karl Bühler in Vienna, and successor of Pál Harkai Schiller as chair. While practically all the contacts with western psychology came to a halt, an extensive scholarship program was set up to send scholars to Leningrad and Moscow. A Pavlov Committee was established at the Hungarian Academy of Sciences to advance the rapid Pavlovization of medicine and psychology. Despite the hugely negative effects of this intended unification of thoughts, remarkably, Pavlovization had a positive effect by declaring psychology a biological science, thereby saving it from being completely integrated into the field of the highly ideology-driven pedagogy.

The 1956 revolution and the re-establishment of psychology in the consolidated Kádár regime

With Stalin's death in 1953 changes began in Hungary, as well. Anti-Rákosi opposition in the Party grew stronger, at the same time Rákosi fell out of favor in Moscow with the rise of Nikita Khrushchev. Rákosi was ordered to make Imre Nagy, his chief opponent within the Party, Prime Minister. Nagy closed forced labor-camps, let previously imprisoned communist politicians back into the Party, and cautiously encouraged reforms. This policy earned him popularity in Hungary, but scorn in Moscow. By that time many communist intellectuals got disappointed with the Soviet model and participated in the Petöfi Circle - a dis- 
cussion group supporting Imre Nagy. A secret informer whose job was to surveil Ferenc Mérei reported in 1955 that Mérei was active in the Petőfi Circle (Litván, 1999). He also participated in the on-going "pedagogy-debate" in which his 1949 condemnation was withdrawn (Szabolcs, 2006). Mérei got active in the 1956 revolution as the teacher president of the Revolutionary Student Committee of University Students in Budapest.

The 1956 revolution broke out on October 23rd and was crushed by the Russian intervention by the end of November. Imre Nagy was arrested and replaced by János Kádár, new leader of the Party, who carried out a brutal retaliation, including large-scale executions and imprisonment. Imre Nagy was executed and György Lukács, who was minister in the revolutionary Nagy government, was also persecuted. ${ }^{18}$ Miklós Gimes, son of Lilly Hajdú and a committed communist before 1956, was also executed for his revolutionary activities - the mother committed suicide in 1960 (Borgos, 2009). Mérei was charged with subversive activities and was sentenced to 10 years in prison. Approximately 200,000 people ( $2 \%$ of the population) emigrated as it became clear that the revolution would be crushed (Lénárt, 2012).

Seeking stability and social support Kádár started to introduce pragmatist and reform-oriented policies in the early 1960's, while still being a loyal satellite to the Soviet Union, where Khrushchev launched the second wave of de-Stalinization. Due to moderate economic reforms the standard of living rose and political oppression was relaxed. In a wave of amnesty imprisoned 1956-ers, including Ferenc Mérei, were freed. The secret police, using a network of ordinary people recruited to be secret informers was still in the business of surveillance of a large segment of the population. Political dissents were persecuted, and the Communist Party (called now the Hungarian Socialist Workers' Party) exercised full ideological control. However, the consolidated Kádár regime combined oppression with limited cultural and academic freedom, which gradually increased throughout the following decades.

Psychology started to revitalize in this political atmosphere. The usefulness of professional knowledge provided by psychology and other previously condemned sciences (genetics, cybernetics) became acknowledged in the Soviet Union, and also in Hungary. Gradually psychology's position changed from being considered as "hostile" to acceptable (see Kovai, 2015, for a detailed discussion). In 1958 the Psychological Committee of the Hungarian Academy of Sciences was set up, with eight sub-committees, presenting wide-scale plans for the future. The Committee decided to re-launch psychology as a major at Eötvös Lóránd (formerly Péter Pázmány) University, beginning in the 1963-64 academic year (Pléh, 1997). The first small class of psychologists graduated with a diploma in 1968 (Pléh, 1999) - at a time when psychology was for long a well-established profession in the West. 
In the 1960's academic psychology had some room to develop under the Pavlovian umbrella. In the still overly politicized world of science (as well as in other areas of intellectual life) a general social game was to balance between the official Marxist line and meaningful autonomous work. This was done easier in fields of psychology closer to natural sciences, such as psychophysiology. In this area significant experimental work was conducted by researchers Endre Grastyán at the university of Pécs, and others (e.g. György Ádám, György Karmos, and Magda Marton) at the Institute of Psychology of the Hungarian Academy of Sciences. In less naturalistic research areas scientific positions gained hidden political messages and symbolic meaning. Specifically, the study of instrumental conditioning over Pavlovian classical conditioning (the orthodox official line) became a subtle stand against "forced" associations and a passive organism - eventually based on the implicit analogy of classical conditioning and political indoctrination. Likewise, research on motivation and informal group processes were in a way hidden agendas to explore agency and freedom in human activity (Pléh, 1999).

During the 1960s Imre Hermann had his weekly seminars for a handful of selected followers who attended these meetings in his apartment. Although, requests to organize a legitimate psychoanalytic society were rejected by the officials, slowly and gradually psychoanalysis became tolerated instead of being banned (Hidas, 1998). Nevertheless, it remained very difficult for psychoanalysts behind the Iron Curtain to keep contact with western colleagues. In 1968 they initiated negotiations with the International Psychoanalytic Association to work out ways for Hungarians to join again. In 1968, twenty years after the abolishment of the Hungarian Psychoanalytic Association, Hungarians painfully had to apply for IPA membership and go through individual accreditation, including Imre Hermann, a founding member of the Budapest School (Hidas, 1998).

From 1964 Ferenc Mérei worked at the National Neurological and Mental Hospital (Lipótmezö), where he founded the Clinical Psychology Laboratory. These years Mérei became a central figure in the re-emerging Hungarian psychology. The Laboratory served as an unofficial training center and Mérei himself grew into the role of an "archetypal network guru" promoting informal professional group life, which turned out to be highly effective in nurturing a new generation of psychologists (Bagdy, Forgács and Pál, 1989, Pléh, 1997, Erős, 2005). Mérei further developed his developmental - social - sociometric research agenda and with his collaborates published books of educational and clinical relevance that have been used by generations of psychologists.

Starting in 1974, young psychoanalysts informally organized the so-called Psychotherapy Weekends (Harmatta, 2006). It took certain courage to participate in these weekends because psychoanalysis was still under ideological attacks and the Ministry of Internal Affairs and the Hungarian Academy of Science conducted "examinations" to decide if psychotherapy weekends were related to 
the political opposition. Finally György Aczél, the iconic cultural politician of the Kádár era decided that the movement belonged to the "tolerated" category of intellectual life (Hidas, 1998). ${ }^{19}$ The psychotherapy movement was important in the formation of a new generation of clinical psychologists.

By 1989, when the rule of the Communist Party ended, Hungarian psychology had a long and difficult history. Its roots and avenues were diverse, but continuity with its past, and in many ways even the awareness of it, was multiply broken. Yet, this history also proved that in the $20^{\text {th }}$ century psychology has become an integral part of the social world and that it was far from being a field that politics could ignore.

\section{Psychology as a "Hungarian Phenomenon"}

Stanislav Ulam, the famous mathematician invented the phrase "Hungarian Phenomenon", referring to the outstanding Hungarian mathematicians, physicists and chemists of the 20th century by stating: "Budapest, in the period of the two decades around the First World War, proved to be an exceptionally fertile breeding ground for scientific talent ... their names abound in the annals of mathematics and physics of the present time" (Ulam, 1958, 2, see also: Palló, 2000, Nye, 2011). We can safely say, however, that the concentration of talent in Hungary in the first part of the $20^{\text {th }}$ century extended beyond the physical sciences, and it included psychology. The "Hungarian phenomenon" in this wider sense was rooted in Central European-Hungarian culture in several ways.

Hungarian intellectual life in the early $20^{\text {th }}$ century had a variety of cultural traditions, but perhaps the most basic element was being part of the wider social-cultural space, which was in the dynamic change of belated modernization. Being part of this space meant the lack of barriers regarding language and ideas, but with a special Hungarian point of view, rooted in the love and hate relationship with the Habsburgs and Austria, including a long history of freedom fights. This mix of identity might have played a role in launching Hungarian intellectual creativity.

Members of the Hungarian intelligentsia were broadly educated: classical culture, the arts and the sciences were jointly present and expressly supported by the school system. Ideas were interbreeding. For Leó Szilárd it was matter-of-course to read Freud and to ecommend it to others (Békés, 2004), and it was commonplace for the Polanyi family to host psychoanalytic lectures in the family home (Békés, 2008). For a psychologist like Ferenczi it came naturally to nourish friendship with literary figures, and Franz Alexander recounts how much he was influenced by the networks around his father, Bernát Alexander, who was a significant philosopher at the time (Pléh, 1997). Cross-fertilization across professional circles 
and schools of thought was characteristic in psychology. As pointed out, the psychoanalyst Leopold Szondi worked initially at Paul Ranschburg's experimental laboratory, the psychoanalyst Imre Hermann was assistant to the experimental psychologist Géza Révész, the developmentalist and social psychologist Ferenc Mérei was a devoted disciple of Szondi. David Rapaport worked at the same time as a psychoanalyst and a student of Harkai Schiller in Budapest (Pléh, 1997).

Considering the social-cultural background of the "Hungarian phenomenon", the major role of Jewish Hungarians has to be highlighted. The Hungarian Jewry, in many ways a non-homogeneous social group, produced an unprecedented number of young talents in Hungarian cultural and scientific life, including psychology. The "Martians" were all of Jewish background, like many leading figures in Hungarian psychology. As young people they grew up typically in nonobservant or even converted families that placed great emphasis on achievement in a Janus-faced society which, on the one hand welcomed assimilated Jews, on the other hand raised glass walls for them in various ways (Patai, 1996, Nye, 2011). It is no accident that Hungary became the first cradle of psychoanalysis outside of Vienna, and Hungarian psychoanalysis developed in such a rich and distinctive way. The shared experience of being Jewish within the Austro-Hungarian sociocultural conditions evidently created mutual resonance among Jewish intellectuals in Vienna and in Budapest. Scholarship suggests that psychoanalysis does in fact have its roots in Jewish identity and the Judaic traditions (Bakan, 1958, Frosh, 2005, Yerushalmi, 1991, Zborowski and Herzog, 1995). The outsider status, along with a sense of "secularized messianism" made minds ready for a critical and radical theory, especially at a time when modernization shook the region. For a Hungarian Jewish intellectual, with a medical degree, western orientation, German language skills, the attraction of psychoanalysis, as well as interest in psychology as a natural science, came naturally.

Dismally, the heavy Jewish presence in psychology and intellectual life in general concluded either in repeated emigration or in persecution and genocide. Paradoxically, this happened with an assimilated Jewish scientist population, for whom their Jewish background was typically insignificant. In the context of Hungarian psychology we find the general norm of joint work of scientists regardless of religious background (just to mention Ranschburg's, Szondi's, or Mérei's environment). Those who stayed (e.g. Ranschburg, Hermann) experienced the help and support of gentile friends (Ranschburg, 2013). These facts, however, could not hinder the severe and tragic losses suffered.

Between the two World Wars Hungarian psychology was strong enough to flourish and extend its infrastructure in a social-economic-political setting which was constraining as much as it was supportive. Characteristically, academic brands of psychology, as well as psychoanalysis had strong connections with applied practice. Hungarian depth psychologists not only were object-rela- 
tion theorists decades before the term was coined in the psychoanalytic literature (Deri, 1990), but also used the insight on the importance of early mother-infant relationship to develop practical interventions in education (Vajda, 1995). Likewise, Ranschburg, Szondi, Várkonyi, Harkai Schiller and others showed a vivid interest in applied problems of child psychiatry, special education, and vocational training (Völgyesy, 1995). The child study movement was especially instrumental in influencing and integrating various approaches and direct them to support social progress.

As much as the aftermath of World War I brought unredeemable losses, so did the aftermath of World War II - only this time Hungarian psychology got fully severed from the West, where it always belonged. Initially it seemed that communist psychologists, many of them in significant positions (e.g. Ferenc Mérei, Imre Hermann, Lilly Hajdú) could have greatly contributed to the emerging post-war new world. But the Stalinist system soon showed that it did not tolerate any autonomy even by those who fought for its victory. The consolidated Kádár regime created a deal: those in power tolerated a certain amount of intellectual freedom, and those who received this freedom accepted the rules of the communist regime. Collective memory became a tool of collective loss of remembrance (Máriássi, 2015). A citation analysis (Pléh, 1979) showed that between 1958 and 1975 in Hungarian journals no citations were made to non-living pre-war Hungarian psychologists. By the 1970s amnesia was prevalent in the psychology community about many pre-war leading Hungarian psychologists. The Hungarian Catholic tradition almost completely faded out of national and international consciousness (Pléh, 2005). Hungarian historians of psychology have made great strides in recent years, but one of them still asks today: Why do we not have Ranschburg's legacy as a living tradition? Why do we still not have a monograph on his life and work? (Lányi, 2013b, 44).

\section{Coming back from forgetfulness}

To reconstruct a deliberately forgotten past takes time, especially as oblivion was not only a national, but also an international phenomenon. Writing about the Hungarian avant-garde artists, Mansbach (1994) noted that "the entire culture of "Mitteleuropa" has been overwhelmed by the tumultuous events of political history, to the extent that this entire region (geographical as well as cultural) has been forcibly propelled from the center of our consciousness to the periphery of Western awareness" (Mansbach, 1994, 10).

Actually, the past is making its way into the present, as it is the case with Ferenczi's legacy. Since the publication of his Clinical Diary in 1985 and the Freud-Ferenczi correspondence (Brabant, Falzeder and Giampieri-Deutsch, 
1993, Falzeder, Brabant and Giampieri-Deutsch, 1996) his work has been gradually reevaluated and given substantial acknowledgement (Rudnytsky, Bókay and Giampieri-Deutsch, 1996, Szekacs-Weisz and Keve, 2012). The opening of the Sándor Ferenczi Center at the New School for Social Research (New York) in 2009, and the Budapest-based international Ferenczi Center and Ferenczi house in 2011 also attest to the reinforced interest in his work. Ferenczi is now considered as having initiated a paradigm shift in psychoanalysis that has made his work highly important for post-Freudian psychoanalysis and contemporary psychotherapy at large (Rudnytsky, 1996, Giampieri-Deutsch, 1996, Curtis, 1996). The work of Melanie Klein, Margaret Mahler, René Spitz, and Harry Harlow is clearly recognized as having roots in Ferenczi's approach to psychoanalysis (Klein was Ferenczi's analyzed; Mahler and Spitz, being also Hungarians, were influenced by Hungarian psychoanalysis, see Vikár, 1996).

However, the reclaiming of the past is a much more complex process than making good on the intellectual accomplishments of those "unjustly forgotten" (which is, nevertheless, an obligation). Along with their achievements we should also see psychologists of the past as actors in historical times. The Hungarian perspective makes a vivid case against the apolitical, decontextualized view of psychology. The history of Hungarian psychology was intertwined, in a very tangible sense, with the political history of the Central European region. Not only as being victimized by the circumstances, but also by psychology being sensitive and actively responsive to social and political demands.

We have to explore in greater depth the particular social-cultural conditions in this specific Central European region that inspired and constrained the phenomenon of psychology, but we also have to uncover how psychology acted to build a modernized society under these conditions, and how it thrived, suffered, and survived under dictatorships and undemocratic regimes. We have to explore, in greater depth, what Hungarian emigration meant for international psychology. We also have to ask how Hungarian psychology tried to come to terms with its own past during the Kádár regime, and how Hungarian psychology, as it stands today, is embedded in its own past, in spite of the "tradition of broken traditions". ${ }^{20}$

To know the past is especially relevant where remembrance was once so forcefully obstructed. The scholarship on the history of Hungarian psychology is growing at a fast pace. The richness of this history, however, has yet to become more fully explored and appreciated inside and outside of Hungary. 


\section{Notes}

1 In the Handbook of International Psychology (Stevens and Wedding, 2004), for example, "East Europe" is represented by Poland, Russia, and Turkey. In The Oxford Handbook of the History of Psychology: Global Perspectives (Baker, 2012) there is one chapter on Czech psychology (Hoskovec, 2012). Mansbach (1994), on speaking about early 20th century Hungarian avantgarde art, observes how "Eastern Europe", and along with it Hungary, was, to a considerable degree, lost to western consciousness after W.W.II, as a periphery.

2 Csaba Pléh (1997, available in both Hungarian and in English) provided a brief overview of Hungarian contributions to modern psychology, and highlighted characteristics of Hungarian development, and he authored substantially on the history of experimental psychology and other topics. The historiography of certain topics - for example, Hungarian psychoanalysis - has received ample attention in the past decades (see the references by Ferenc Erös, Judit Mészáros and many others). Other topics and periods - the post World War II, for example, have moved into focus recently (e.g. Máriási, 2015, Kovai, 2015). The literature on the history of Hungarian psychology is definitely growing.

3 About the complexity of Hungarian identity from a narrative social psychology perspective, see László, 2014.

4 Lechner also won first prize in the World Exhibit in Paris, in 1900, for the cephalograph (an instrument to measure the outlines of the head) he invented (Fodor and Kós, 1995).

5 "Psychotechnik" was the generally accepted original German term for the field of applied psychology (Benjamin and Baker, 2012).

6 Révész studied at various German universities and became friends with pre-Gestalt phenomenal psychologists David Katz and Edgar Rubin, worked with Karl Stumpf in Berlin and was in close relationship with Franz Brentano. In 1906 he returned to Budapest and started to work at Pázmány University, doing experimental studies on hearing and music. He worked hard to establish the new science, and was appointed professor of psychology and head of a to-beorganized experimental psychology department in 1918 originally by the administration of the royal government. The appointment was approved by the liberal burgeois government and then by the Hungarian Soviet regime. He had no time to fulfill his appointment because of the quick fall of the communist regime. In 1920 he emigrated and moved to the University of Amsterdam where he continued successful research. (About Révész see Piéron, 1956, Pléh, 2009).

7 During the communist rule between 1949 and 1989 this event was officially regarded as a revolution by the people. In the past two decades a re-evaluation has taken place among historians, several of them calling the take-over a coup d'etate, pointing out that the communists came to power as a result of back-stage negotiations without the knowledge of the state president Mihály Károlyi. The nature and role of the Hungarian Soviet Council is still a debated subject.

8 The Communist Party was illegal in the Horthy regime. The nature of the Horthy regime, likewise the evaluation of the Hungarian Soviet Republic, is an unsettled issue in Hungary even today, debated by historians.

9 Szondi exerted lasting influence on prominent later figures in Hungarian psychology, for example Ferenc Mérei, István Benedek, Lajos Kardos, and Flora Kozmutza.

10 Legally the Hungarian Psychoanalytic Society was in business even under the German occupation, due to the fact that a non-Jewish leadership took over in order to save the organization (Mészáros, 2012).

11 On the NÉKOSZ see Pataki (2005) and in English: The generation of "Bright Winds": A generation denied, by Judith Szapor (2013).

12 According to estimates from an original population of approximately 800,000-861,000 Jewish population about 80,000-255,000 survived (History of Jews in Hungary, Wikipedia). 
13 Zionism was the idea of Tivadar (Theodor) Herzl, a Hungarian Jew. On Herzl see Shlomo Avinery: Theodor Herzl and the foundation of the Jewish state (2013).

14 Erös: in many families children were raised so that they were not aware that they were Jews.

15 The Great Purge infected many communists. Among others, Béla Kun, leader of the Hungarian Soviet Republic, who lived in the Soviet Union, was also arrested and executed.

16 After participating in the Hungarian Soviet Republic György Lukács lived in Vienna, Berlin, and then in Moscow. In 1945 he came back to Hungary, became member of the Academy of Sciences and member of Parliament. In the 1950's he conducted ardent criticism against noncommunist thinkers and writers. At the same time, he was also criticized by the leading ideologist, József Révai.

17 The novel Darkness at noon by the Hungarian born British novelist Arthur Koestler (1968) engagingly describes the psychology of such trials in a story of a Bolshevik revolutionary.

18 Lukács engaged in self-criticism and remained loyal to communism, but following the crush of the uprising in Czechoslovakia in 1968 he became critical of the Soviet Union and the Kádár regime. In the 1960's he formed what later became called the Budapest School in philosophy, adherent to the renewal of Marxism. The school exerted significant influence on the development of western Marxism. As a brief summary see "The Development of the Budapest School", by George Lukács, in The Times Literary Supplement, No. 3615, June 11, 1971.

19 It was widely known that Aczél's cultural policy was based on the " 3 T's" - meaning that any cultural product or phenomenon had to be classified in one of three categories: either "supported", or "tolerated", or "unpermitted".

20 Csaba Pléh, Gusztáv Lányi, psychoanalyst Ferenc Erős, Judit Mészáros, along with others, including more recently Kovai, 2015 and Máriási, 2015 (from a critical psychology point of view) have taken substantial steps in this direction.

\section{References}

Avineri, Shlomo. 2013. Herzl: Theodor Herzl and the Foundation of the Jewish State. London: Weidenfeld \& Nicolson.

Bagdy, Emőke, Forgács, Pál and Pál, Mária (eds.). 1989. Mérei Ferenc (1909-1986): Emlékkönyv születésének 80. évfordulója alkalmából. Budapest: Neotyp.

Bakan, David. 1958. Sigmund Freud and the Jewish Mystical Tradition. Princeton: Van Nostrand.

Baker, David B. (ed.). 2012. The Oxford Handbook of the History of Psychology: Global Perspectives. Oxford, New York: Oxford University Press.

Békés, Vera. 2004. A „konstruktív pesszimizmus” forrásvidéke: A magyar tudományos mühelyek „utolsó polihisztorai” és „titkos klasszikusai” a 20. század első felében. In: Békés, Vera (ed.) A kreativitás mintázatai: Magyar tudósok, magyar intézmények a modernitás kihívásában. Budapest: Áron Kiadó, 130-177.

Békés, Vera. 2008. A Polányi család és a pszichoanalízis. In: Erős, Ferenc, Lénárd, Kata and Bókay, Antal (eds.) Typus Budapestiensis: Tanulmányok a pszichoanalízis budapesti iskolájának történetéröl és hatásáról. Budapest: Thalassa Alapítvány, 15-52.

Benjamin, Ludy T. and Baker, David B. 2012. The Internationalization of Psychology: A History. In: Baker, David B. (ed.) The Oxford Handbook of the History of Psychology: Global Perspectives. Oxford, New York: Oxford University Press, 1-10.

Bergman, Martin S. 1996. The Tragic Encounter between Freud and Ferenczi and Its Impact on the History of Psychoanalysis. In: Rudnytsky, Peter L., Bókay, Antal and Giampieri-Deutsch, Patrizia (eds.) Ferenczi's Turn in Psychoanalysis. New York: New York University Press, 145-159. 
Berman, Marshall. 1982. All That is Solid Melts into Air: The Experience of Modernity. Verso. New York: Simon and Schuster.

Blowers, Geoffrey. 2006. Origins of Scientific Psychology in China, 1899-1949. In: Brock, Adrian C. (ed.) Internationalizing the History of Psychology. New York: New York University Press, 94-111.

Borgos, Anna. 2009. Elhárító mechanizmusok: Pszichoanalízis és politika találkozásai Hajdu Lilly életútjának tükrében. Thalassa, 20 (1), 21-46.

Borgos, Anna, Erős, Ferenc and Litván, György (eds.). 2006. Mérei élet-mü: Tanulmányok. Budapest: Új Mandátum.

Brabant, Eva, Falzeder, Ernst and Giampieri-Deutsch, Patrizia (eds.). 1993. The Correspondence of Sigmund Freud and Sándor Ferenczi. Vol. 1. 1908-1914. Cambridge: Belknap Press of Harvard University Press.

Buklijas, Tatjana and Lafferton, Emese. 2007. Science, Medicine and Nationalism in the Habsburg Empire from the 1840's to 1918. Studies in History and Philosophy of Biological and Biomedical Sciences, 38 (4), 679-686.

Bürgi-Meyer, Karl. 1996. „A laboratórium egy lázasan dolgozó hangyatársadalom”. Thalassa, 7 (2), 83-103.

Csomortáni, D. Zoltán. 2009. Egy reneszánsz egyéniség a XX. századi magyar pszichológiában: Várkonyi Hildebrand Dezső élete és munkássága. In: Szokolszky, Ágnes (ed.) A lélektan 80 éves története a szegedi egyetemen, 1929-2009. Szeged: JATEPress.

Curtis, Rebecca. 1996. A New World Symphony: Ferenczi and the Integration of Nonpsychoanalytic Techniques into Psychoanalytic Practice. In: Rudnytsky, Peter L., Bókay, Antal and Giampieri-Deutsch, Patrizia (eds.) Ferenczi's Turn in Psychoanalysis. New York: New York University Press, 248-265.

Deák, Gábor. 2000. A magyar gyermektanulmányi mozgalom története. 1. Budapest: Fővárosi Pedagógiai Intézet, Magyar Pedagógiai Társaság, Országos Pedagógiai Könyvtár és Múzeum

Deri, Susan. 1990. Great Representatives of Hungarian Psychiatry: Balint, Ferenczi, Hermann and Szondi. Psychoanalytic Review, 77 (4), 491-501.

Dewsbury, Donald A. 1994. Paul Harkai Schiller. Psychological Record, 44, 307-350.

Dewsbury, Donald A. 1996. Paul Harkai Schiller: The Influence of his Brief Career. In: Kimble, Gregory A., Boneau, C. Alan and Wertheimer, Michael (eds.) Portraits of Pioneers in Psychology. Vol. 2. Mahwah: Lawrence Erlbaum, 281-294.

Erős, Ferenc. 2005. Élmény és hálózat: Mérei Ferenc a magyar szociálpszichológia történetében. In: Borgos, Anna, Erős, Ferenc and Litván, György. (eds.) Mérei élet-mü: Tanulmányok. Budapest: Új Mandátum, 127-159.

Erős, Ferenc. 2009. Ferenczi Sándor professzori kinevezése: Háttér és kronológia. Thalassa, 20 (4), 3-28.

Erös, Ferenc. 2011. Pszichoanalizis és forradalom: Ferenczi Sándor és a budapesti egyetem 191819-ben: tanulmány és dokumentumok. Budapest: Jószöveg Kiadó.

Erös, Ferenc. 2012. Some Social and Political Issues Related to Ferenczi and the Hungarian School. In: Szekacs-Weisz, Judit and Keve, Tom (eds.) Ferenczi and His World: Rekindling the Spirit of the Budapest School. London: Karnac, 39-54.

Erős, Ferenc. 2015. A nemzetpolitikai lélektantól a tudományos fajelméletig: A magyar pszichológia történetének szürke zónája. socio.hu, (2), 67-85. Available at: http://socio.hu/uploads/ files/2015_2/eros.pdf [Accessed 8 March 2016].

Falzeder, Ernst, Brabant, Eva and Giampieri-Deutsch, Patrizia (eds.). 1996. The Correspondence of Sigmund Freud and Sándor Ferenczi. Vol. 2. 1914-1919. Cambridge: Belknap Press of Harvard University Press. 
Fodor, Katalin and Kós, Béla. 1995. Lechner Károly, a „psychophisiológia” kolozsvári művelője. In: Kiss, György (ed.) Pszichológia Magyarországon. Budapest: Országos Pedagógiai Könyvtár és Múzeum, 20-30.

Frosh, Stephen. 2005. Hate and the 'Jewish science': Anti-Semitism, Nazism and Psychoanalysis. New York: Palgrave MacMillan.

Furumoto, Laurel. 1989. The New History of Psychology. In: Cohen, Ira S. (ed.) The G. Stanley Hall Lecture Series. Vol. 9. Washington: American Psychological Association, 9-34.

Gao, Zhipeng. 2012. The Emergence of Modern Psychology in China, 1876-1922. Annual Review of Critical Psychology, 10, 293-396.

Geykens, Tomas. 2003. Imre Hermann's Freudian Theory of Attachment. Internatonal Journal of Psychoanalysis, 84 (6), 1517-1529.

Giampieri-Deutsch, Patrizia. 1996. The Influence of Ferenczi's Ideas on Contemporary Standard Technique. In: Rudnytsky, Peter L., Bókay, Antal and Giampieri-Deutsch, Patrizia (eds.) Ferenczi's Turn in Psychoanalysis. New York: New York University Press, 224-247.

Gleimann, Anna, Harkai Schiller, Pál and Herman, Imre. 1945. A közelmúlt lelki tömegfertőzései: A beteg néplélek és annak gyógyitása. Budapest: Pantheon.

Golnhofer, Erzsébet. 2006. Rendszerváltások a tudomány legitimációjában: Magyarország, 19451949. In: Szabolcs, Éva (ed.) Pedagógia és politika a XX. század második felében Magyarországon. Budapest: Eötvös József Könyvkiadó, 9-28.

Gordosné Szabó, Anna. 2013. Ranschburg Pál folyamatos jelenléte a 110 éves magyar gyógypedagógus képzésben - és „elmélkedés” a képzés jövőjéről. In: Lányi, Gusztáv (ed.) Ranschburg Pál és a magyar pszichológia: Ranschburg Pál (1870-1945). Budapest: ELTE Eötvös Kiadó, 89-112.

Gülerce, Aydan. 2006. History of Psychology in Turkey as a Sign of Diverse Modernization and Global Psychologization. In: Brock, Adrian C. (ed.) Internationalizing the History of Psychology. New York: New York University Press, 75-93.

Gyöngyösiné Kiss, Enikő. 1996. Szondi Lipót életmüvéből. Thalassa, 7 (2), 3-4.

Gyöngyösiné Kiss, Enikő. 2010. Personality and the Familial Unconscious in Szondi’s Fate Analysis. Empirical Text and Cultural Research, 4, 70-80. Available at: http://www.szondi.pte.hu/ document/fate-analysis.pdf [Accessed 3 March 2016].

Gyurgyák, János. 2001. A zsidókérdés Magyarországon: politikai eszmetörténet. Budapest: Osiris.

Hargittai, István. 2006. The Martians of Science: Five Physicists Who Changed the Twentieth Century. Oxford, New York: Oxford University Press.

Harmat, Pál. 1994. Freud, Ferenczi és a magyarországi pszichoanalizis: A budapesti mélylélektani iskola története: 1908-1993. Budapest: Bethlen Gábor Könyvkiadó.

Harmat, Pál. 1995. A budapesti pszichoanalitikus iskola. In: Kiss, György (ed.) Pszichológia Magyarországon. Budapest: Országos Pedagógiai Könyvtár és Múzeum, 98-113.

Harmatta, János. 2006. A Pszichoterápiás Hétvégek (1974-1986) története és hatása. 1. Pszichoterápia, 15 (1), 6-18.

Harris, Ben. 2009. What Critical Psychologists Should Know about the History of Psychology. In: Fox, Dennis, Prilleltensky, Isaac and Austin, Stephanie (eds.) Critical Psychology: An Introduction. London: Sage, 20-35.

Haynal, André E. 1996. Freud and His Intellectual Environment: The Case of Sándor Ferenczi. In: Rudnytsky, Peter L., Bókay, Antal and Giampieri-Deutsch, Patrizia (eds.) Ferenczi's Turn in Psychoanalysis. New York: New York University Press, 25-40.

Haynal, André E. 2012. Ferenczi Now and Then: An Introduction to His World. In: Szekacs-Weisz, Judit and Keve, Tom (eds.) Ferenczi and His World: Rekindling the Spirit of the Budapest School. London: Karnac, 69-86. 
Heszen-Niejodek, Irena. 2004. Psychology in Poland: A Country in Transition. In: Stevens, Michael J. and Wedding, Danny (eds.) Handbook of International Psychology. New York: BrunnerRoutledge, 273-291.

Hidas, György. 1998. Önéletrajz. In: Bodor, Péter, Pléh, Csaba and Lányi, Gusztáv (eds.) Önarckép háttérrel: Magyar pszichológusok önéletrajzi írásai. Budapest: Pólya Kiadó, 107-128.

Holowinsky, Ivan Z. 2008. Psychology in Ukraine: A Historical Perspective. Lanham: University Press of America.

Hoskovec, Jiří. 2012. Czech Republic. In: Baker, David B. (ed.) The Oxford Handbook of the History of Psychology: Global Perspectives. Oxford, New York: Oxford University Press, $138-161$.

Hunyady, Orsolya. 2012. Herr Professor and His "Grand Vizir”: The Freud/Ferenczi Relationship in Its Social Context. Contemporary Psychoanalysis, 48 (2), 166-182.

Iványi, János. 2008. Lechner Károly, a kolozsvári, majd a szegedi Elme- és Ideggyógyászati Klinika első igazgatója. Orvostudományi Értesitö, 81 (2), 142-144.

Jakabffy, Éva. (n.d.) Dienes Valéria életmüve. Available at: http://web.archive.org/web/20121116112 753/http://evajakabffy.shp.hu/hpc/web.php?a=evajakabffy\&o=hOE011KqOW [Accessed 3 March 2016].

Joravsky, David. 1989. Russian Psychology: A Critical History. Oxford, Cambridge: Blackwell.

Kahana, Michael Jacob and Jacobs, Joshua. 2000. Interresponse Times in Serial Recall: Effects of Intraserial Repetition. Journal of Experimental Psychology: Learning, Memory, and Cognition, 26 (5), 1188-1197.

Keve, Tom. 2012. Ferenczi Remembered. In: Szekacs-Weisz, Judit and Keve, Tom (eds.) Ferenczi and His World: Rekindling the Spirit of the Budapest School. London: Karnac, 1-30.

Kim, Uichol and Berry, John W. (eds.). 1993. Indigenous Psychologies: Experience and Research in Cultural Context. Newsbury Park: Sage.

Kiss, György. 1991. Az individuálpszichológia megjelenése Magyarországon. In: Arató, Ottó and Kiss, György (eds) Az individuálpszichológia és hatása Magyarországon. Budapest: Tankönyvkiadó, 47-60.

Kiss, György. 1995. A hazai pszichológiatörténeti kutatások eredményei. In: Kiss, György (ed.) Pszichológia Magyarországon. Budapest: Országos Pedagógiai Könyvtár és Múzeum, 8-19.

Koestler, Arthur. 1968. Darkness at Noon. London: Longmans.

Kontler, László. 2002. A History of Hungary: Millenium in Central Europe. Houndsmill, Basingstoke: Palgrave Macmillan.

Kovai, Melinda. 2015. Lélektan és (köz)politika: Pszicho-tudományok a magyarországi államszocializmusban 1945-1970. Manuscript.

Kozulin, Alex. 1984. Psychology in Utopia: Toward a Social History of Soviet Psychology. Cambridge: MIT Press.

Kundera, Milan. 1984. The Tragedy of Central Europe. The New York Review of Books, 31 (7), 33-38.

Lafferton, Emese. 2003. A History of Hungarian Psychiatry, 1850-1908. PhD Dissertation. Budapest: Central European University.

Lafferton, Emese. 2004. Magántébolydától az egyetemi klinikáig: A magyar pszichiátria történetének vázlata európai kontextusban, 1850-1908. In: Békés, Vera (ed.) A kreativitás mintázatai: magyar tudósok, magyar intézmények a modernitás kihívásában. Budapest: Áron Kiadó, 34-73.

Lányi, Gusztáv. 1997. Lélekelemzés és politika: A pszichoanalitikus politikai pszichológiák Magyarországon. Valóság, 40 (3), 1-14.

Lányi, Gusztáv. 1999. Rejtőzködés és (ön)rostálás: A pszichológia magyarországi viszonyairól a fordulat évétől (1948/49) 1956-ig. Magyar Pszichológiai Szemle, 54 (2), 195-203. 
Lányi, Gusztáv. 2013a. Ranschburg Pál és a magyar pszichológiatörténet-írás. In: Lányi, Gusztáv (ed.) Ranschburg Pál és a magyar pszichológia: Ranschburg Pál (1870-1945). Budapest: ELTE Eötvös Kiadó, 7-11.

Lányi, Gusztáv (ed.). 2013b. Ranschburg Pál és a magyar pszichológia: Ranschburg Pál (18701945). Budapest: ELTE Eötvös Kiadó.

László, János. 2014. Historical Tales and National Identity: An Introduction to Narrative Social Psychology. London, New York: Routledge.

Lénárt, András. 2012. Emigration from Hungary in 1956 and the Emigrants as Tourists to Hungary. Hungarian Historical Review, 1 (3-4), 368-396.

Lendvai, Paul. 2014. The Hungarians: A Thousand Years of Victory in Defeat. Princeton: Princeton University Press.

Lisznyai, Sándor. 1999. A magyar individuálpszichológiai mozgalom 1945 utáni története. Magyar Pszichológia Szemle, 54 (2), 167-178.

Litván, György. 1999. Mérei és a „Krampusz”. Beszélö, 4 (2), 60-70.

Lukacs, John. 1990. Budapest 1900: A Historical Portrait of a City and Its Culture. New York: Grove Press.

Mansbach, Steven E. 1994. Foreward. Hungarian Studies, 9 (1-2), 9-14.

Máriási, Dóra. 2015. Amikor a pszichológia a "kommunizmus általánosan kibontakozó építésének nagyszerü programjához” csatlakozott: Újraintézményesülés kritikai perspektívában. Alkalmazott Pszichológia. Manuscript.

Marton, Magda. 1996. Harkai Schiller tudományos szemlélete harminc év néhány felismerésének tükrében. Pszichológia, 16 (2), 115-129.

Marx, George. 1994. The Voice of the Martians. Budapest: Roland Eötvös Physical Society.

Marx, György. 2000. A marslakók érkezése: magyar tudósok, akik Nyugaton alakitották a 20. század történelmét. Budapest: Akadémiai Kiadó.

Mérei, Ferenc. 1949. Group Leadership and Institutionalization. Human Relations, 2 (1), 23-29.

Mészáros, Judit. 1998. The Tragic Success of European Psychoanalysis: "The Budapest School". International Forum of Psychoanalysis, 7 (4), 207-214.

Mészáros, Judit. 2009. Sándor Ferenczi and the Budapest School of Psychoanalysis. Psychoanalytic Perspectives, 7 (1), 69-89.

Mészáros, Judit. 2012. Effects of Dictatorial Regimes on the Psychoanalytic Movement in Hungary before and after World War II. In: Damousi, Joy and Plotkin, Mariano Ben (eds.) Psychoanalysis and Politics: Histories of Psychoanalysis under Conditions of Restricted Political Freedom. New York: Oxford University Press, 79-112.

Montgomery, John Flournoy. 1947. Hungary: The Unwilling Satellite. New York: Devin-Adair Co.

Moreau-Ricaud, Michelle. 1996. The Founding of the Budapest School. In: Rudnytsky, Peter L., Bókay, Antal and Giampieri-Deutsch, Patrizia (eds.) Ferenczi's Turn in Psychoanalysis. New York: New York University Press, 41-59.

Moreau-Ricaud, Michelle. 2012. Healing Boredom: Ferenczi and His Circle of Literary Friends. In: Szekacs-Weisz, Judit and Keve, Tom (eds.) Ferenczi and His World: Rekindling the Spirit of the Budapest School. London: Karnac, 87-96.

Morton, Frederic. 1989. Thunder at Twilight: Vienna 1913/1914. New York: Scribner.

Nemes, Lívia. 1986. Psychoanalysis in Hungary: Its past and present situation. Psychoanalysis in Europe Bulletin, 26, 83-92.

Nemes, Lívia. 1996. Az enfant terrible alakja a pszichoanalízisben. Thalassa, 7 (3), 40-52.

Nye, Mary Jo. 2011. Michael Polanyi and His Generation: Origins of the Social Construction of Science. Chicago, London: The University of Chicago Press.

Palló, Gábor. 2000. The Hungarian Phenomenon in Israeli Science. Bulletin for the History of Chemistry, 25 (1), 35-42. 
Palló, Gábor. 2007. Klebelsberg Kuno: politikus kultuszminiszter. Magyar Tudomány, 168 (12), $1619-1628$.

Palló, Gábor. (n.d.). The Rockefeller Foundation's Activity in Hungary. Rockefeller Archive Center Research Reports Online. Available at: http://www.rockarch.org/publications/resrep/pallo2.pdf [Accessed 5 March 2016].

Paranjpe, Anand C. 2006. From Tradition through Colonialism to Globalization: Reflections on the History of Psychology in India. In: Brock, Adrian C. (ed.) Internationalizing the History of Psychology. New York: New York University Press, 56-74.

Patai, Raphael. 1996. The Jews of Hungary: History, Culture, Psychology. Detroit: Wayne State University Press.

Pataki, Ferenc. 2005. A Nékosz-legenda. Budapest: Osiris Kiadó.

Pickren, Wade E. and Rutherford, Alexandra. 2010. A History of Modern Psychology in Context. Hoboken: Wiley.

Piéron, Henry. 1956. Géza Révész: 1878-1955. The American Journal of Psychology, 69 (1), 139141.

Pléh, Csaba. 1979. A magyar pszichológia fejlődésének néhány jellemzője a publikációk mennyiségi elemzésének tükrében 1958-1975. Magyar Tudományos Akadémia Filozófia és Történettudományok Osztályának Közleményei, 28 (1-3), 209-231.

Pléh, Csaba. 1984. Hagyomány és újitás a magyar pszichológiában, avagy a hagyományfelejtés mint pszichológiai hagyomány. Világosság, 25 (3), 153-157.

Pléh, Csaba. 1997. Hungarian Contributions to Modern Psychology. Hungarian Studies, 12 (1-2), 47-71.

Pléh, Csaba. 1999. The Symbolic of Psychology under a Totalitarian System: The case of Hungary in the 1960's. In: Hacker, Winfried and Rinck, Mike (eds.) Schwerpunktthema "Zukunft gestalten": Bericht über den 41. Kongress der Deutschen Gesellschaft für Psychologie in Dresden 1998. Lengerich: Pabst Science Publishers, 109-122. (Reprinted in Pléh, Csaba. 2008. History and Theories of the Mind. Budapest: Akadémiai Kiadó, 183-194.)

Pléh, Csaba. 2005. The Catholic Tradition at the Beginnings of Hungarian Psychology: Harkai, Dienes, Schütz. Hungarian Studies, 19 (1), 187-197.

Pléh, Csaba. 2009. A korai magyar kísérleti pszichológia és a nagyvilág: Révész Géza emlékére. Magyar Pszichológiai Szemle, 64 (3), 467-495.

Pléh, Csaba. 2011. A Magyar kísérleti pszichológia fejlödési íve 1950-2010 között. Magyar Pszichológiai Szemle, 66 (4), 669-693.

Pléh, Csaba. 2014. Pszichológusok és történészek: A pszichológiatörténet müvelésének két célcsoportja és két műfaja. Magyar Pszichológia Szemle, 69 (3), 547-565.

Pléh, Csaba, Bodor, Péter and Lányi, Gusztáv. 1998. Egy társadalomtudomány elnyomatása és újjászületése: A magyar pszichológia sorsa az egyéni sorsok tükrében, 1945-1970. In: Bodor, Péter, Pléh, Csaba and Lányi, Gusztáv (eds.) Önarckép háttérrel: Magyar pszichológusok önéletrajzi irásai. Budapest: Pólya Kiadó, 303-310.

Pók, Attila. 1994. Modern Sociology and Modern Art in Early Twentieth Century Hungary. Hungarian Studies, 9 (1-2), 65-71.

Ranschburg, Ágnes Hildegard. 2013. Elismerések és elöítéletek kereszttüzében: Ranschburg Pál életútja a családi dokumentumok tükrében. In: Lányi, Gusztáv (ed.) Ranschburg Pál és a magyar pszichológia: Ranschburg Pál (1870-1945). Budapest: ELTE Eötvös Kiadó, 113-144.

Romsics, Ignác. 2010. Magyarország története a XX. században. Budapest: Osiris.

Rudnytsky, Peter L. 1996. Introduction. Ferenczi's Turn in Psychoanalysis. In: Rudnytsky, Peter L., Bókay, Antal and Giampieri-Deutsch, Patrizia (eds.) Ferenczi’s Turn in Psychoanalysis. New York: New York University Press, 1-24. 
Rudnytsky, Peter L., Bókay, Antal and Giampieri-Deutsch, Patrizia (eds.). 1996. Ferenczi’s Turn in Psychoanalysis. New York: New York University Press.

Sáska, Géza. 2008. Alkalmazott lélektan és reformpedagógia 1945 után. Beszélö, 13 (2), 28-38.

Schwarcz, Vera. 1999. Strangers No More: Personal Memory in the Interstices of Public Commemoratin. In: Watson, Rubie S. (ed.) Memory, History and Opposition: Under State Socialism. Santa Fe: School of American Research Press, 45-64.

Stevens, Michael J. and Wedding, Danny (eds.). 2004. Handbook of International Psychology. New York: Brunner-Routledge, 273-291.

Sugár, Peter F., Hanák, Péter and Frank, Tibor (eds.). 1994. A History of Hungary. Bloomington: Indiana University Press.

Szabó, Júlia. 1994. European Art Centers and Hungarian Art (1890-1919). Hungarian Studies, 9 (1-2), 41-64.

Szabolcs, Éva (eds.). 2006. Pedagógia és politika a XX. század második felében Magyarországon. Budapest: Eötvös József Könyvkiadó.

Szapor, Judith. 2013. The Generation of 'Bright Winds': A Generation Denied. In: Berghoff, Hartmut, Jensen, Uffa, Lubinski, Christina, and Weisbrod, Bernd (eds.) History by Generations: Generational Dynamics in Modern History. Göttingen: Wallstein Verlag, 239-257.

Szegedy-Maszák, Mihály. 1994. Conservatism, Modernity, and Populism in Hungarian Culture. Hungarian Studies, 9 (1-2), 15-40.

Szekacs-Weisz, Judit and Keve, Tom (eds.). 2012. Ferenczi and His World: Rekindling the Spirit of the Budapest School. London: Karnac.

Taiana, Cecilia. 2006. Transatlantic Migration of the Disciplines of the Mind: Examination of the Reception of Wundt's and Freud's Theories in Argentina. In: Brock, Adrian C. (ed.) Internationalizing the History of Psychology. New York: New York University Press, 34-55.

The Brunswick Society. Available at: http://www.brunswik.org/index.html [Accessed 5 March 2016].

Torda, Ágnes. 1995. Egy tudományos mühely létrejötte a századfordulón. In: Kiss, György (ed.) Pszichológia Magyarországon. Budapest: Országos Pedagógiai Könyvtár és Múzeum, 31-55.

Ulam, Stanisław. 1958. John von Neumann, 1903-1957. Bulletin of the American Mathematical Society, 64 (3), 1-49.

Vajda, Zsuzsanna. 1995. A pszichoanalizis budapesti iskolája és a nevelés. Budapest: Sík Kiadó.

Valenstein, Elliot S. 2011. Behind the Iron Curtain: Psychology, Neuroscience, and Politics in the Soviet Union. North Charleston: CreateSpace Independent Publishing Platform.

Várdy, Steven Béla. 2012. Hungarian Immigrants. Available at: http://immigrationinamerica. org/560-hungarian-immigrants.html [Accessed 5 March 2016].

Vikár, György. 1996. The Budapest School of Psychoanalysis. In: Rudnytsky, Peter L., Bókay, Antal and Giampieri-Deutsch, Patrizia (eds.) Ferenczi's Turn in Psychoanalysis. New York: New York University Press, 60-76.

Völgyesy, Pál. 1995. A pályaválasztási tanácsadás történetének áttekintése hazánkban. In: Kiss, György (ed.) Pszichológia Magyarországon. Budapest: Országos Pedagógiai Könyvtár és Múzeum, 73-97.

Yerushalmi, Yosef Hayim. 1991. Freud's Moses: Judaism terminable and interminable. New Haven: Yale University Press.

Zborowski, Mark and Herzog, Elizabeth. 1995. Life is with People: The Culture of the Shtetl. New York: Schocken Books. 